\title{
Investigation of different infill wall effects on performance of steel frames with shear beam-column connections under progressive collapse
}

\author{
Mohammed Alrubaidi ${ }^{a}$ (D) Alhammadi, S. A. ${ }^{\text {b* }}$ (i) \\ ${ }^{a}$ Department of Civil Engineering, King Saud University, Riyadh, Saudi Arabia. E-mail: Maalrubaidi@gmail.com \\ bVice Rectorate for Facilities and Operation, Princess Nourah bint Abdulrahman University, Riyadh, Saudi Arabia. \\ E-mail: saalhammadi@pnu.edu.sa
}

*Correspondence

https://doi.org/10.1590/1679-78256983

\begin{abstract}
This article examined steel frames with shear beam-column connections to determine the effectiveness of different masonry infill walls under progressive collapse. This research concentrated on the shear connection, which is the most common type of steel beam-column connection in steel buildings. Furthermore, this work experimentally evaluated one-third-scale steel-framed configurations with a single shear beam-column connection and another infilled steel frame wall configuration from the literature to verify the validity of 3D finite element models developed using the program ABAQUS. Finite element models were then used to investigate 16 different kinds of steel frames with infill masonry as well as the influence of multiple frames and the number of stories. In addition, the effects of a fully infilled frame and those of a bare frame and an infilled frame with openings were compared in flexural and catenary action phases. Results revealed that the steel building's structural strength and energy dissipation against progressive collapse are significantly improved by infill walls.
\end{abstract}

\section{Keywords}

FEM; Steel frame; Infill wall; shear beam-column connection; Progressive collapse; Catenary action.

\section{Graphical Abstract}

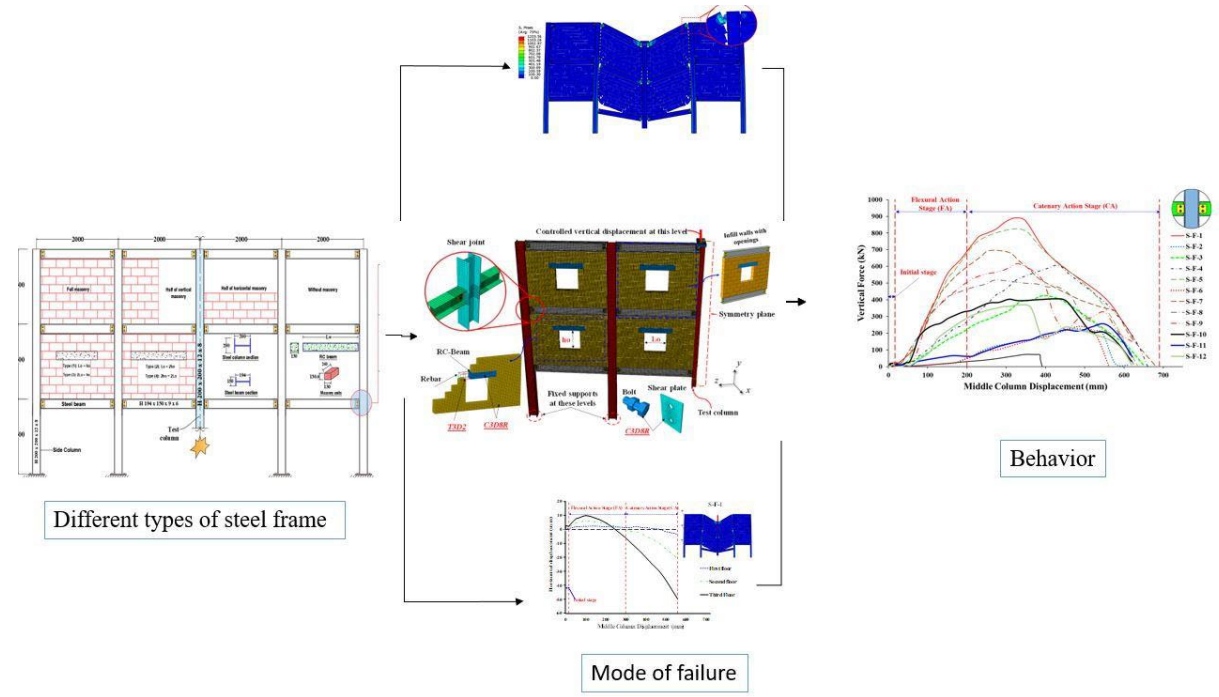




\section{INTRODUCTION}

Steel-framed multi-story structures are exposed to a wide variety of operational circumstances and situations during their service life. Thus, the structure's design must provide enough structural resistance and durability to accommodate these factors. Even if the building's designers considered all possible dangers, an unplanned event (such as a blast or fire) might harm the structure on a local level. When one element of a structure is damaged, the damage spreads to other components, thus causing a significant amount of the building to collapse (or even causing the whole building to collapse). For instance, on September 11, 2001, the Twin Towers in New York were destroyed by a bombing, and Ronan Point in London was taken down by a gas explosion in 1968 (McGuire, 1974; Leyendecker and Ellingwood, 1977).

During the past decade, several studies have investigated the progressive collapse of buildings exposed to accidental loads; however, the majority of studies have concentrated on bare framed structures and not filled frames, while little research has explored reinforced concrete (RC) buildings (Yu et al., 2019; Wang et al., 2020). Several experiments have examined the structural behavior of bare steel-frame single-story beam-column assemblies (Alrubaidi et al., 2020; Khandelwal et al., 2009; Kim and Kim, 2009; Kim and An, 2009) and multistory steel frames (Qian and Hu, 2008; Tavakoli and Alashti, 2013; Dinu et al., 2015) under a central-column-loss scenario. With regard to the central-column loss scenario, several numerical investigations have concentrated on high fidelity simulation with solid parts (Tan et al., 2021; Kiakojouri et al., 2021; Elsanadedy et al., 2021), as well as on macro simulation (Fu et al., 2016; Purnomo and Chandra, 2020; and Wang and Wang, 2021).

Masonry infill walls are often used as facades or partitions in steel frame projects across the globe. In the event of a progressive collapse, masonry infill walls may affect the mechanical performance of frame systems positively or negatively. For RC buildings with partial masonry infill walls, Sasani and Sagiroglu (2008) and Sasani (2008) found that infill walls significantly reduced the overall structural deformations during field tests and numerical studies. In addition, Shan et al. (2016) studied the effects of infill walls on the progression of collapse in two one-third-scale, four-span, two-story RC frame buildings to identify the impact of quasi-static load and column removal scenarios. They determined that infilled walls may increase the resistance to progressive collapse by functioning as compressive struts that alternately distribute removal column stresses. Ductility may be reduced, which would modify the failure process, for rigid composite structures. Furthermore, the risk of damage to RC frame constructions increases when the resistance force of infilled walls is greater. More than one researcher has used a prior study's experimental data to verify their numerical findings (e.g., (Eren et al., 2019; Li et al., 2016; Yu et al., 2019)). Woodson and Baylot(2000) examined the effect of infilled walls on RC structures during progressive collapse on five quarter-scale (two-story) specimens subjected to blast loading. As the applied weight was reduced, the infilled walls had a significant influence on decreasing the column's explosive repercussions. Additionally, the blast pressure on the slab floors underneath the slabs on which these walls were constructed was significantly reduced as a result of the construction of these walls. The weight was transferred to the corner columns by the edge beams that extended over the missing column, thus avoiding gradual collapse.

Research on the effect of infill walls on the mechanical performance of RC frames in progressive collapse scenarios has only been conducted in a few cases in the past. Furthermore, few studies have examined the role of masonry infill walls in the progressive collapse of steel frame buildings. Steel frames are more ductile and bendable than RC frames, as they are made of more ductile materials. As a consequence of the lower cross-sectional area and greater buckling potential of steel frame beams and columns, the interactions between infill walls and frame components may vary from those of RC frame beams and columns. Infill walls with a shear beam-column connection, which is the most common connection used across the globe in infilled steel frame structures, have been overlooked in previous research efforts.

Shan et al. (2019) investigated the influence of masonry infill walls on progressive collapse mechanisms in steel frames. An open-frame, full-height infill wall and a partial-infill wall structure were all created. According to their research, infill walls have a significant impact on the maximum applied vertical load and the initial rigidity. However, this effect reduces ductility and alters the steel frame's failure processes. By compressing and bracing infill walls diagonally, researchers found that the steel frames migrate outward and the beams flex in various directions. In addition, the researchers found that the progressive collapse performance of infilled steel frames is highly influenced by the mortar connections and opening dimensions. Field tests were done by Song and Sezen (2013) and Song et al. (2014) by removing four first-story columns from pre-existing steel frames and filling them with masonry. Although brick infill walls play a part in the overall behavior, their involvement was not expressly mentioned. Xavier et al. (2017) used a full-scale quasi-static test program to investigate steel frames with masonry infill walls subjected to pushdown loads. With high displacements, masonry infill walls are destroyed, whereas steel frames retain considerable resistance. Research on the pushdown resistance of limited masonry infill walls uses only masonry infill walls, beams, and restrained columns as test specimens. However, brick infill walls have not been examined in relation to the gradual collapse processes of entire planer steel frames. 
Studies on steel-framed structures have previously been inconclusive on how the shear beam-column connection affects the infilled steel frame and how many stories are affected by a progressive collapse. Under a middle column loss scenario, a steel shear beam-column connection was examined experimentally for the possibility of 2D assemblies collapsing from this perspective and due to the restricted facilities in our laboratory. The test frames were made up of three columns and two beams. In addition, the experiment needed to adhere to ANSI/AISC 358-16 (ANSI, 2016a) while creating the shear-connection specimen. Removing the center column and applying a vertical downward force at $100 \mathrm{~mm} / \mathrm{s}$ to the steel frames replicated the progressive collapse due to column loss. Nonlinear rate-dependent material behavior and interface contact between steel components were modeled in 3D finite element (FE) simulations using ABAQUS software (2020). Shan et al.'s (2019) infill wall steel frame test assembly was used to evaluate the FE model parameters.

Then, the performance of progressive collapse resistance for 16 distinct kinds of steel frames with masonry infill walls was studied using the confirmed finite element models. We looked into the effects of several frame types, including fully infilled, bare, and infilled with openings, as well as the impact of different numbers of frames and stories. The performance of the infilled frame's openings in relation to shear beam-column connections was examined in detail. Masonry infill walls were compared in flexural and catenary action phases on the basis of their mechanisms of failure and load-displacement response.

\section{EXPERIMENTAL SPECIMENS AND TEST SETUP}

The framing plan of the building in addition to the 2D assembly is depicted in Figure 1. For this study, the steel frame assembly was reduced to one-third of the original size. Each of the prototype steel structure's steel columns had $6 \mathrm{~m}$ in between (Figure 1). To test the missing center column scenario, two components of the prototype steel building's framing were taken and tested. The one-story 2D test assembly is shown in Table 1 and Figure 1b. Using shear beam-column connections, a one-story 2D assembly was built as a standard against which other specimens may be compared. Three steel columns with a center-to-center spacing of $2 \mathrm{~m}$ and a total column height of $2 \mathrm{~m}$ were used in the steel frame assembly (Figure 1b). In Figures 2a, the shear steel beam-column connection of the test steel frame is depicted in great detail. According to Table 1 and Figure 1, the steel frame assembly was fabricated from rolled sections $\mathrm{H} 194 \mathrm{X} 150 \mathrm{~mm}$ beams and H 200 X 200 mm columns.

Table 1 Details of the experimental specimens used in the FE validation*

\begin{tabular}{|c|c|c|c|c|c|c|}
\hline \multirow[b]{2}{*}{ Reference } & \multirow{2}{*}{ Specimen ID } & \multirow{2}{*}{$\begin{array}{c}\text { Type of } \\
\text { Connections }\end{array}$} & Steel Column & Steel Beam & \multirow[b]{2}{*}{ Type of Bolt } & \multirow[b]{2}{*}{ Size plate $(\mathrm{mm})$} \\
\hline & & & $\begin{array}{c}H \times B \times t_{f} \times t_{w} \\
(m m)\end{array}$ & $\begin{array}{c}H \times B \times t_{f} \times t_{w} \\
(m m)\end{array}$ & & \\
\hline \multirow[t]{2}{*}{ Current study } & Ex-S & Shear & $\begin{array}{c}\mathrm{HW} 200 \times 200 \times \\
12 \times 8\end{array}$ & $\begin{array}{c}\text { HM } 194 \times 150 \times 9 \\
\times 6\end{array}$ & G 10.9 M16 & shear plate \\
\hline & & & & & & $120 \times 100 \times 6$ \\
\hline $\begin{array}{c}\text { Study of } \\
\text { Shan et al. (2019) }\end{array}$ & $\begin{array}{l}\text { One floor-infilled } \\
\text { frame }\end{array}$ & Welded & $\begin{array}{c}\text { HW } 350 \times 350 \times \\
12 \times 19\end{array}$ & $\begin{array}{c}\mathrm{HM} 294 \times 200 \times 8 \\
\times 12\end{array}$ & - & - \\
\hline
\end{tabular}

${ }^{*} \mathrm{H}=$ depth of section depth; $\mathrm{B}=$ width of section width; $\mathrm{t} f=$ thickness of steel section flange; tw = thickness of steel section web.

As indicated in Figure 2a, a single plate shear connection was used on specimen Ex-S. The steel beam web was attached to a 6-mm-thick tab plate using two M16, grade 10.9 bolts. The steel shear plate was attached to the column flange using fillet welding. In compliance with AISC-LRFD, the welded beam-column connection was created (ANSI, $2016 b)$. The constraint of the lateral out-of-plane movement of steel beams and the excessive rotation at the end of columns was needed for the test set-up and equipment to acquire the full-scale structure's behavior and replicate the influence of adjacent stories. Beams have a lateral bracing system, as illustrated in Figure $1 \mathrm{~b}$, and the columns above the beam level have a partial extension to achieve this set-up (with top ends constrained). The steel frame's center column was loaded with a $1000 \mathrm{kN}$ hydraulic high-speed actuator under servo control to simulate its removal from the frame system. The actuator had a $500 \mathrm{~mm}$ stroke. To replicate the progressive collapse scenario, the central column support was removed, and a vertical load of $100 \mathrm{~mm} / \mathrm{s}$ was given to this column. The displacement, connection rotation, and stresses were measured by strategically placing instruments throughout the test frame. The exact measurement of beam displacements was made possible by the use of laser transducers positioned at different points along the beams. 
Downward loads were given to the middle column under displacement control by gradually increasing the actuator's vertical displacement until failure was reached. To measure beam stresses, post-yield strain gages were installed at key places on steel beam-column connections.

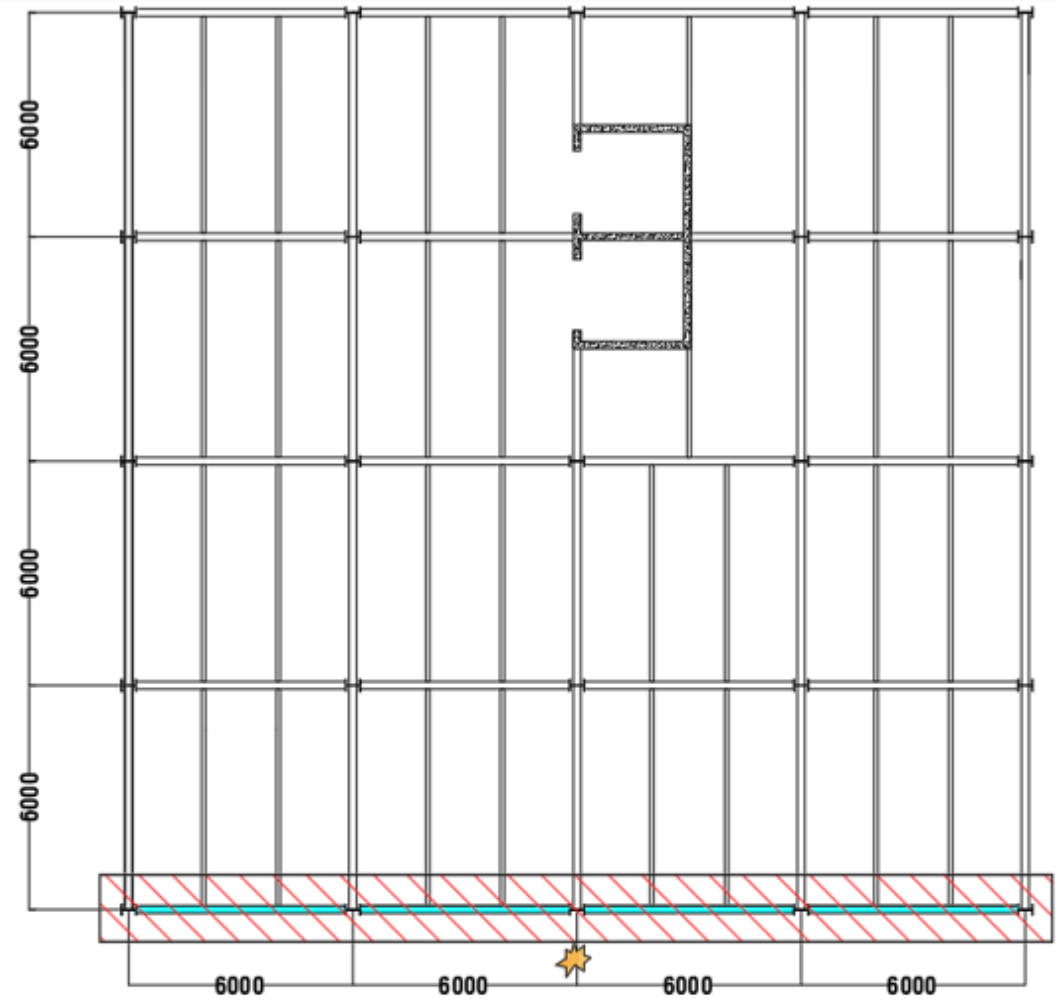

(a)

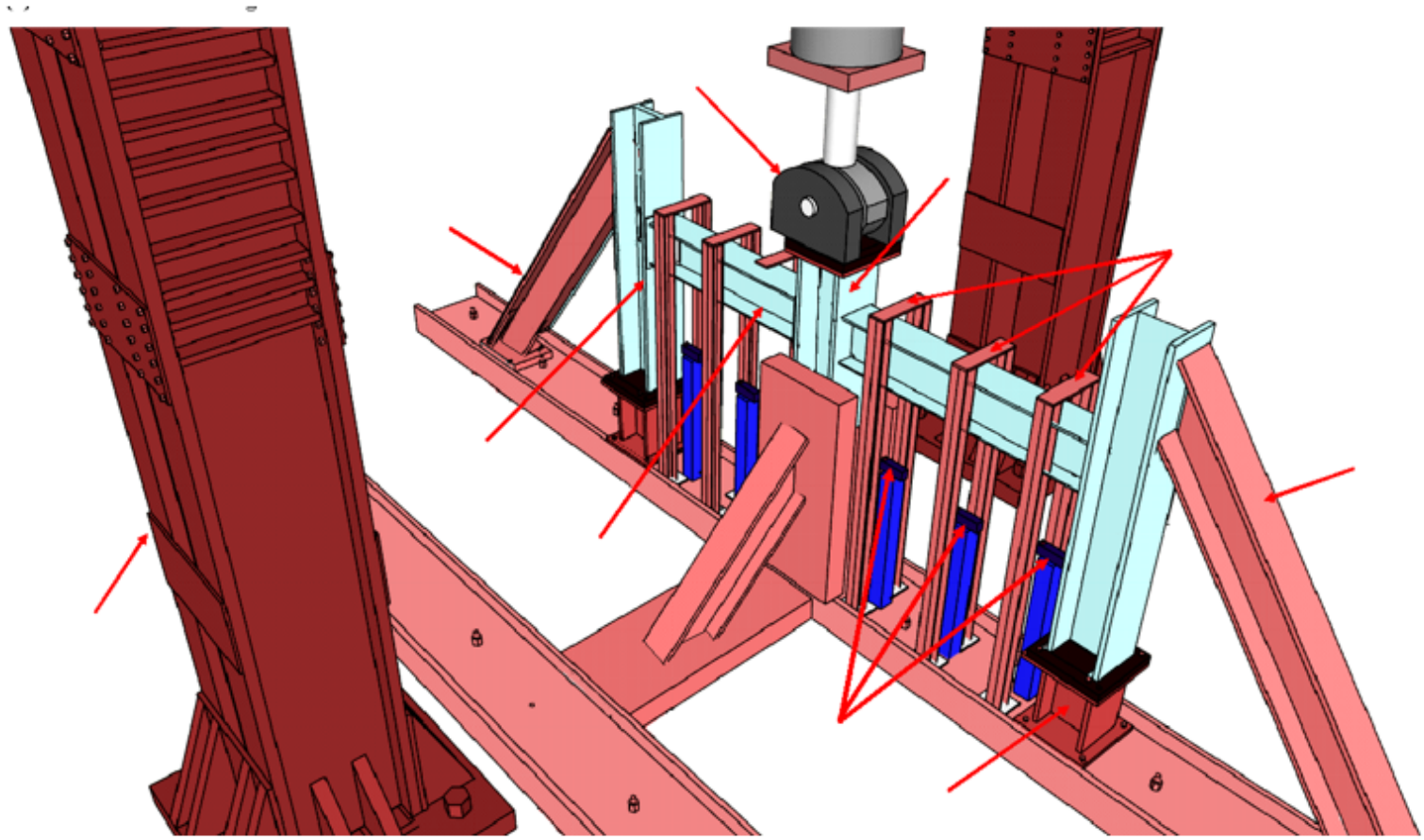

(b)

Figure 1: (a) Plan view of prototype steel building; (b) Test setup and instrumentation layout for experimental one floor specimens (Dimensions are in $\mathrm{mm}$ ). 

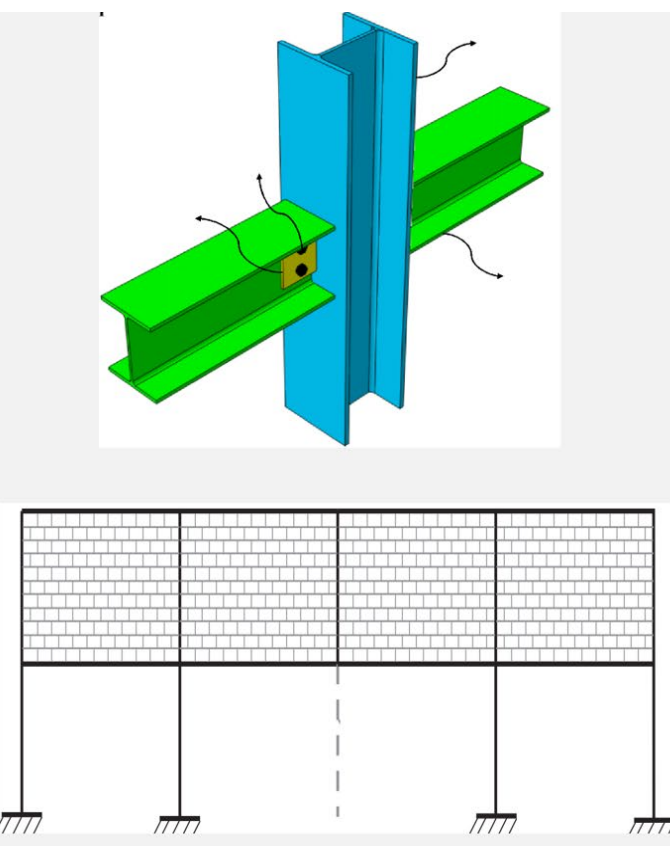

(a)
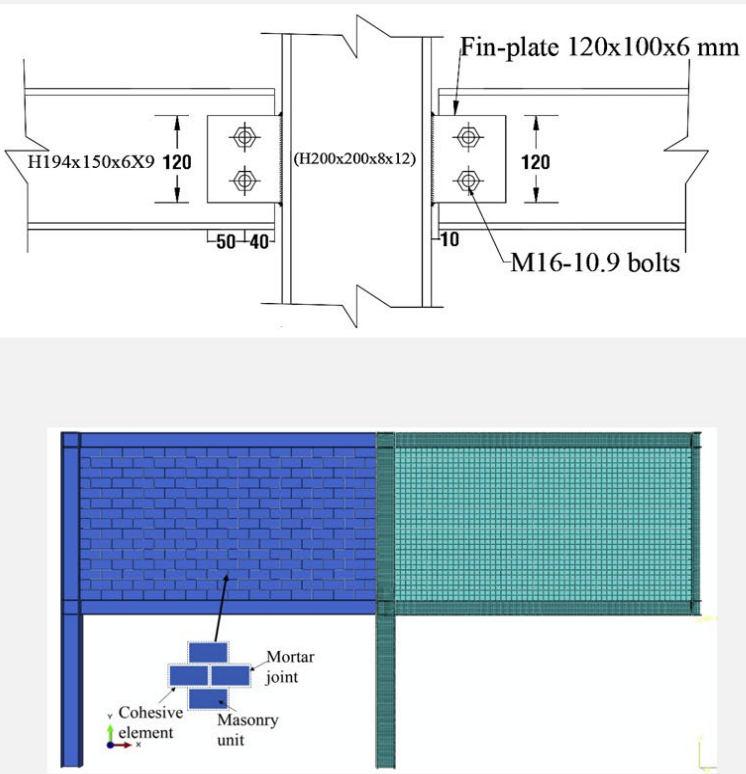

(b)

Figure 2: Details of specimens used for FE validation: (a) Shear connection specimen of current study (Ex-S); (b) Infilled frame specimen tested by Shan et al. (2019).

\section{EXPERIMENTAL RESULTS}

The shear steel frame assembly investigated experimentally in the present study is listed in Table 2, which includes the results of the tests performed on it. The results for the specimen examined by Shan et al. (2019) are presented in the table as well. To obtain a complete view of the load-displacement curve, these results include the following: (a) the force at the bottom flange of the steel beam at the inner steel column face, (b) the peak forces of the flexural and catenary action stages, (c) the downward displacement of the center steel column at the yielding of the bottom flange of the steel beam at the inner connection, (d) the down-displacement of the center column at peak forces of the flexural and catenary action stages, (e) the down-displacement of the center column, (f) the peak axial force in the steel beam at the catenary action stage, (g) the dissipated energy at the ultimate state, $(\mathrm{h})$ the rotation of the steel beam at peak force, and (i) the failure mode.

$\mathrm{Nu}, \mathrm{CA}$ beam axial forces were measured using strain gages that monitored the axial strain change in steel sections. To determine the beam's axial force, the normal stresses derived from the strains were used to calculate the distribution of the stresses. The rotations of the steel beam's ends (è) were assumed to be the same. In addition, flexural resistance $(\mathrm{Pu}, \mathrm{FA})$ can be broken down into two parts: catenary action resistance $(\mathrm{Pu}, \mathrm{CA})$ and total assembly resistance $(\mathrm{Pu})$. The following formula can be used to estimate these elements:

$\mathrm{Pu}, \mathrm{CA}=2 \mathrm{Nu}, \mathrm{CA}$ sinè,

$\mathrm{Pu}, \mathrm{FA}=\mathrm{Pu}-\mathrm{Pu}, \mathrm{CA}$.

According to Table 2, flexural and catenary action phase maximum vertical loads were calculated using Eqs. (1) and (2). The results of the tests performed on each specimen are summarized in the table below.

The control specimen EX-S failure mode is shown in Figure 3a. If a steel column failed due to excessive load, steel buildings with steel shear connections were at risk of progressive collapse. With such weak moment-resisting capabilities and simple (shear) connections, the specimen rotated at both ends as the mid-span deflection rose. Figure 4a depicts the load-displacement characteristics for specimen EX-S. Figure 4 shows that the specimen could withstand low loads up to $75 \mathrm{~mm}$ displacement Figure 4a. Tensile beam axial force was generated at $92 \mathrm{~mm}$ displacement, thus indicating the start of catenary behavior. Bolt holes in the shear plate flexed as a result of the increased load. When the load level reached $73 \mathrm{kN}$, the right shear tab completely broke, thus causing the frame to collapse (Figures 3a and 4a). The central column had moved down $386 \mathrm{~mm}\left(\mathrm{e}=11.9^{\circ}\right)$ at this point. 
Table 2 Comparison of experimental and FE results*

\begin{tabular}{|c|c|c|c|c|c|c|c|c|c|c|c|c|c|c|c|}
\hline \multirow[b]{2}{*}{$\begin{array}{l}\text { Specimen } \\
\text { ID }\end{array}$} & \multirow{2}{*}{$\begin{array}{c}\text { No. } \\
\text { of } \\
\text { floor }\end{array}$} & \multirow[b]{2}{*}{$\begin{array}{c}\text { Result } \\
\mathrm{s}\end{array}$} & \multicolumn{4}{|c|}{ Flexural action stage } & \multicolumn{4}{|c|}{ Catenary action stage } & \multirow[b]{2}{*}{$\begin{array}{l}\mathrm{Pu} \\
\text { (kN) }\end{array}$} & \multirow{2}{*}{$\begin{array}{c}\text { Äu } \\
(\mathrm{mm})\end{array}$} & \multirow[b]{2}{*}{$\begin{array}{c}\mathrm{Eu} \\
(\mathrm{kN} . \mathrm{m})\end{array}$} & \multirow{2}{*}{$\begin{array}{c}\text { è } \\
\text { (degree) }\end{array}$} & \multirow{2}{*}{$\begin{array}{c}\text { Mode } \\
\text { of } \\
\text { failure }\end{array}$} \\
\hline & & & $\begin{array}{c}P_{y} \\
(k N)\end{array}$ & $\begin{array}{c}\ddot{A}_{y} \\
(m m)\end{array}$ & $\begin{array}{l}P_{u, F A} \\
\text { (kN) }\end{array}$ & $\begin{array}{l}\ddot{A}_{\mathrm{u}, \mathrm{c}-\mathrm{FA}} \\
(\mathrm{mm})\end{array}$ & $P_{u, C A}(k N)$ & $\begin{array}{c}\mathbf{P}_{\mathrm{u}, \mathrm{CA}} / \\
\mathbf{P}_{\mathrm{u}, \mathrm{FA}}\end{array}$ & $\begin{array}{l}\ddot{A}_{\mathrm{u}, \mathrm{c}-\mathrm{CA}} \\
(\mathrm{mm})\end{array}$ & $\begin{array}{l}N_{u, C A} \\
(k N)\end{array}$ & & & & & \\
\hline \multirow[t]{3}{*}{ Ex-S } & One & EXP & - & - & 9 & 92 & 72.6 & 8.07 & 375 & 172 & 72.6 & 386 & 12.5 & 11.9 & \multirow{3}{*}{$\begin{array}{c}\text { Fractur } \\
\text { e of tab } \\
\text { plate }\end{array}$} \\
\hline & & $\mathrm{FE}$ & - & - & 9 & 92 & 71.5 & 7.94 & 383 & 172 & 71.5 & 383 & 12.7 & 11.8 & \\
\hline & & EXP/FE & - & - & 1.00 & 1.00 & 1.02 & 1.02 & 0.98 & 1.00 & 1.02 & 1.01 & 0.98 & 1.01 & \\
\hline \multirow{3}{*}{$\begin{array}{l}\text { Study of } \\
\text { Shan et al } \\
\text {. (2019) }\end{array}$} & Two & EXP & 546 & 28 & 728 & 139 & 967 & 1.32 & 1307 & 542 & 967 & 1644 & 1318 & - & \multirow{3}{*}{$\begin{array}{c}\text { Fractur } \\
\text { e of } \\
\text { beam }\end{array}$} \\
\hline & & $\mathrm{FE}$ & 541 & 33 & 703 & 163 & 944 & 1.34 & 1458 & 529 & 944 & 1582 & 1136 & - & \\
\hline & & EXP/FE & 1.01 & 0.85 & 1.03 & 0.85 & 1.02 & 0.99 & 0.90 & 1.02 & 1.02 & 1.03 & 1.16 & - & \\
\hline
\end{tabular}

${ }^{*} \mathrm{Py}=$ load at first yield of beam bottom flange at inner column face; $\Delta y=$ displacement of middle column at first yield of beam bottom flange at inner column face; $\mathrm{Pu}, \mathrm{FA}=$ peak load of flexural action stage; $\triangle \mathrm{u}, \mathrm{c}-\mathrm{FA}=$ displacement of middle column at peak load of flexural action stage; $\mathrm{Pu}, \mathrm{CA}=\mathrm{peak}$ load of catenary action stage; $\Delta \mathrm{u}, \mathrm{c}-\mathrm{CA}=$ displacement of middle column at peak load of catenary action stage; Nu,CA = peak beam axial force at catenary action stage; $\mathrm{Pu}=$ progressive collapse resistance; $\Delta \mathrm{u}=$ displacement of middle column at ultimate state; Eu = energy dissipated at ultimate state; and $\theta=$ beam rotation at maximum load.

\section{FE MODELING}

This section presents a numerical program created using the ABAQUS (2020) software. The program investigated the effect of different infill walls on the progressive collapse performance of a steel structure with a shear beam-column connection. The calibration and verification of the experimental test in the current research, as well as other studies gathered from the literature and reported in this article, served as the foundation for the FE modeling program. The FE modeling was divided into five sections: (i) material modeling, (ii) mesh generation, (iii) loading and boundary conditions, (iv) FE model validation, and (v) models for parametric analysis.

Table 3 Input parameters for material models used in the FE modeling.

\begin{tabular}{|c|c|c|c|c|c|c|c|}
\hline \multirow{2}{*}{ Stage } & \multirow{2}{*}{$\begin{array}{l}\text { Name of input } \\
\text { parameter }\end{array}$} & \multicolumn{6}{|c|}{ Value of input parameter } \\
\hline & & Column flange & Column web & Beam flange & Beam web & Shear plate & Bolt class 10.9 \\
\hline \multirow[t]{3}{*}{ Elastic } & $\begin{array}{l}\text { Young's modulus } \\
\text { (GPa) }\end{array}$ & 205 & 212 & 194 & 196 & 194 & 210 \\
\hline & Poisson's ratio & 0.3 & 0.3 & 0.3 & 0.3 & 0.3 & 0.3 \\
\hline & Density (Tons/mm3) & $7.85 \times 10-9$ & $7.85 \times 10-9$ & $7.85 \times 10-9$ & $7.85 \times 10-9$ & $7.85 \times 10-9$ & $7.85 \times 10-9$ \\
\hline Plastic & $\begin{array}{c}\text { True stress-strain } \\
\text { curve }\end{array}$ & see Figure 6 & see Figure 6 & see Figure 6 & see Figure 6 & see Figure 6 & see Figure 6 \\
\hline $\begin{array}{l}\text { Damage of } \\
\text { ductile }\end{array}$ & Fracture strain* & 0.55 & 0.56 & 0.6 & 0.61 & 0.6 & 0.21 \\
\hline
\end{tabular}

*Determined from the true stress-strain curves shown in Figures 6

Table 4 Mechanical properties for concrete used in the FE modeling.

\begin{tabular}{|c|c|c|c|c|c|c|c|}
\hline \multirow{2}{*}{$\begin{array}{l}\text { Compressive strength } \\
\text { (MPa) }\end{array}$} & \multicolumn{2}{|c|}{ Elastic } & \multicolumn{5}{|c|}{ Plastic } \\
\hline & $\begin{array}{l}\text { Elastic } \\
\text { Modulus } \\
\text { (MPa) }\end{array}$ & Poisson's ratio & $\begin{array}{l}\text { Dilation angle } \\
\text { (ö) }\end{array}$ & $\begin{array}{l}\text { Eccentricity } \\
(\epsilon)\end{array}$ & Fbo/Fco & Kc & $\begin{array}{c}\text { Viscosity } \\
\text { Parameter }(\mu)\end{array}$ \\
\hline 30 & 30588.5 & 0.15 & 36 & 0.1 & 1.16 & 0.667 & 0.0005 \\
\hline
\end{tabular}



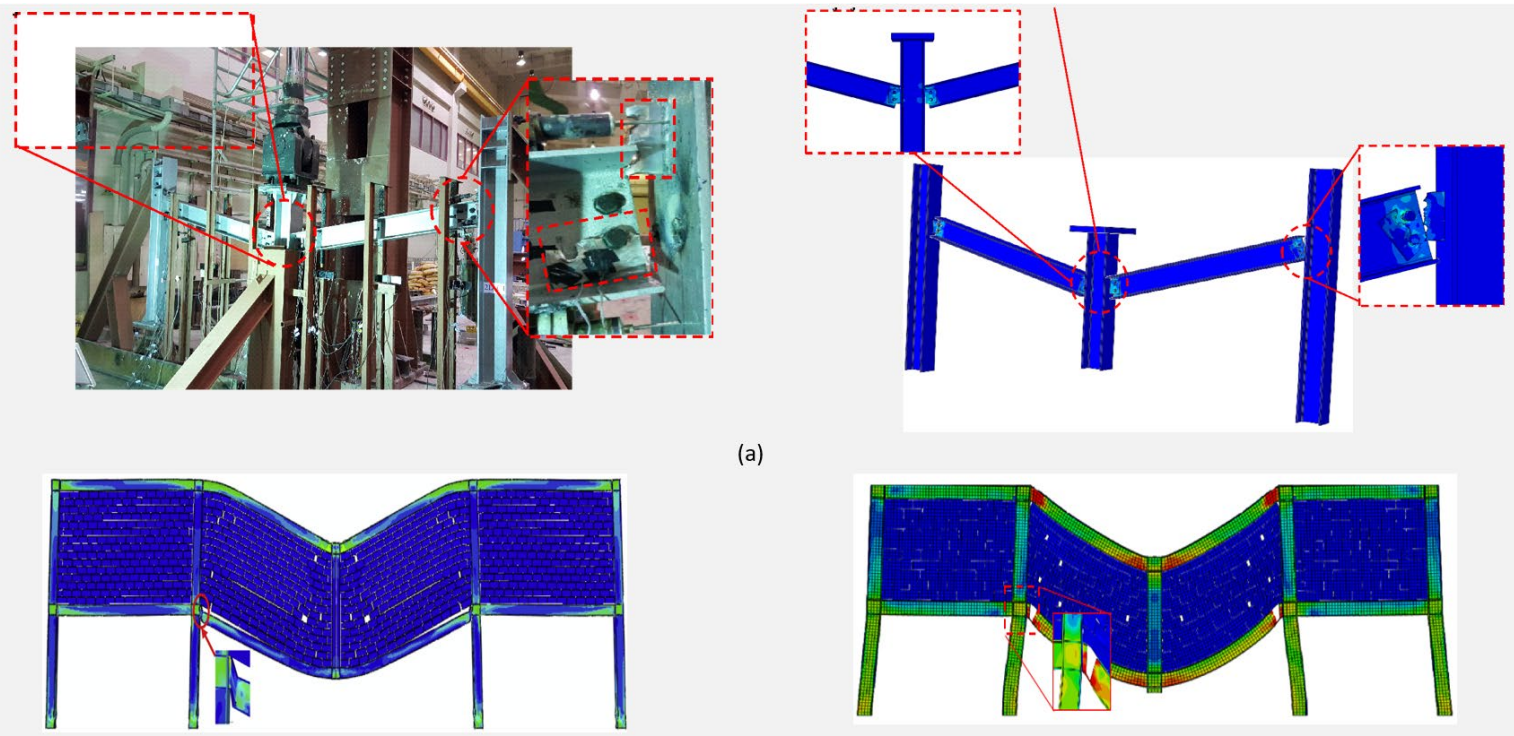

(a)

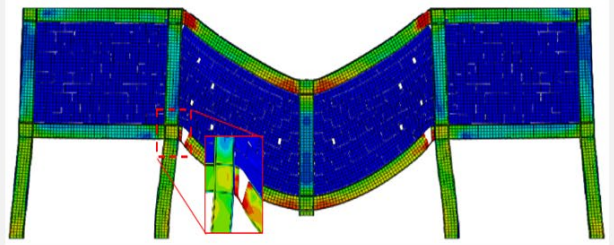

Figure 3: FE mode of failure for: (a) Specimen Ex-S of current study; (b Specimen tested by Shan et al. (2019).

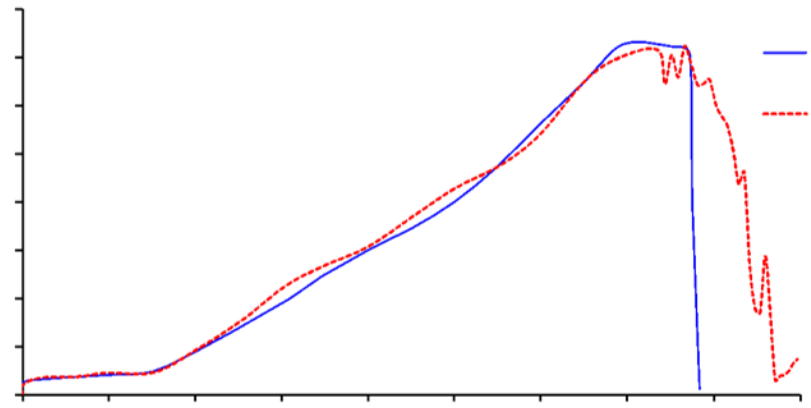

(a)

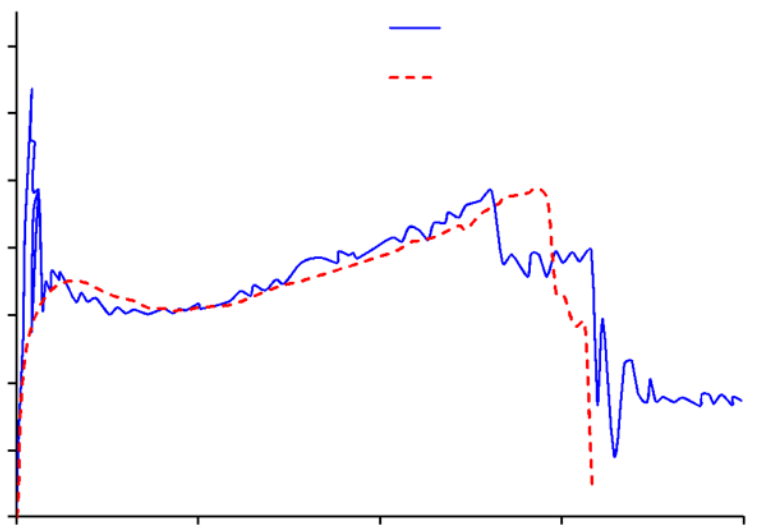

(b)

Figure 4: Comparison of experimental and FE load-displacement curves for: (a) Specimen Ex-S of current study; (b) Specimen tested by Shan et al. (2019).

\subsection{Material modeling}

Tensile tests on standard steel coupons (Figure 5a) were performed in accordance with applicable norms in Ref. (ASTM,2014) for material model input values indicated in Table 3. The following formulae were necessary to transform the engineering stress-strain $(\sigma \mathrm{E}-\varepsilon \mathrm{E})$ curves into true stress-strain (otrue-etrue) curves (CEN, 2006). 
$\sigma_{\text {true }}=\sigma_{E}\left(1+\varepsilon_{E}\right)$,

$\varepsilon_{\text {true }}=\operatorname{In}\left(1+\varepsilon_{E}\right)$

When the maximum force is reached for the coupon test, necking causes the material to harden rather than soften. The material curve for true stress-true strain was considered to have a parabolic shape after reaching the maximum load of the engineering stress-strain curve (Bao and Wierzbicki, 2004; Arasaratnam et al., 2011). Coupon tests on various sections were used to establish the input parameters for the parabolic curve (Figure 6), which were unique for each component (e.g., flange of steel beam, web of steel beam, flange of steel column, web of steel column, and steel plates). The components were used to calibrate the FE model results via coupon testing (Figure 5). The damage for ductile metal approach (Liu et al. 2013) was used to simulate the experimentally observed fracture of steel where the mesh size and shape had a significant impact on material damage characteristics (Alrubaidi et al., 2020; Meng et al., 2018) (Figure 6). Figure 7 depicts a comparison of experimental and FE load-displacement curves for the three coupon types, with high agreement seen between the two curves. This agreement validated the correctness of the material models that would be used in the modeling of 2D and infill wall frame assemblies.

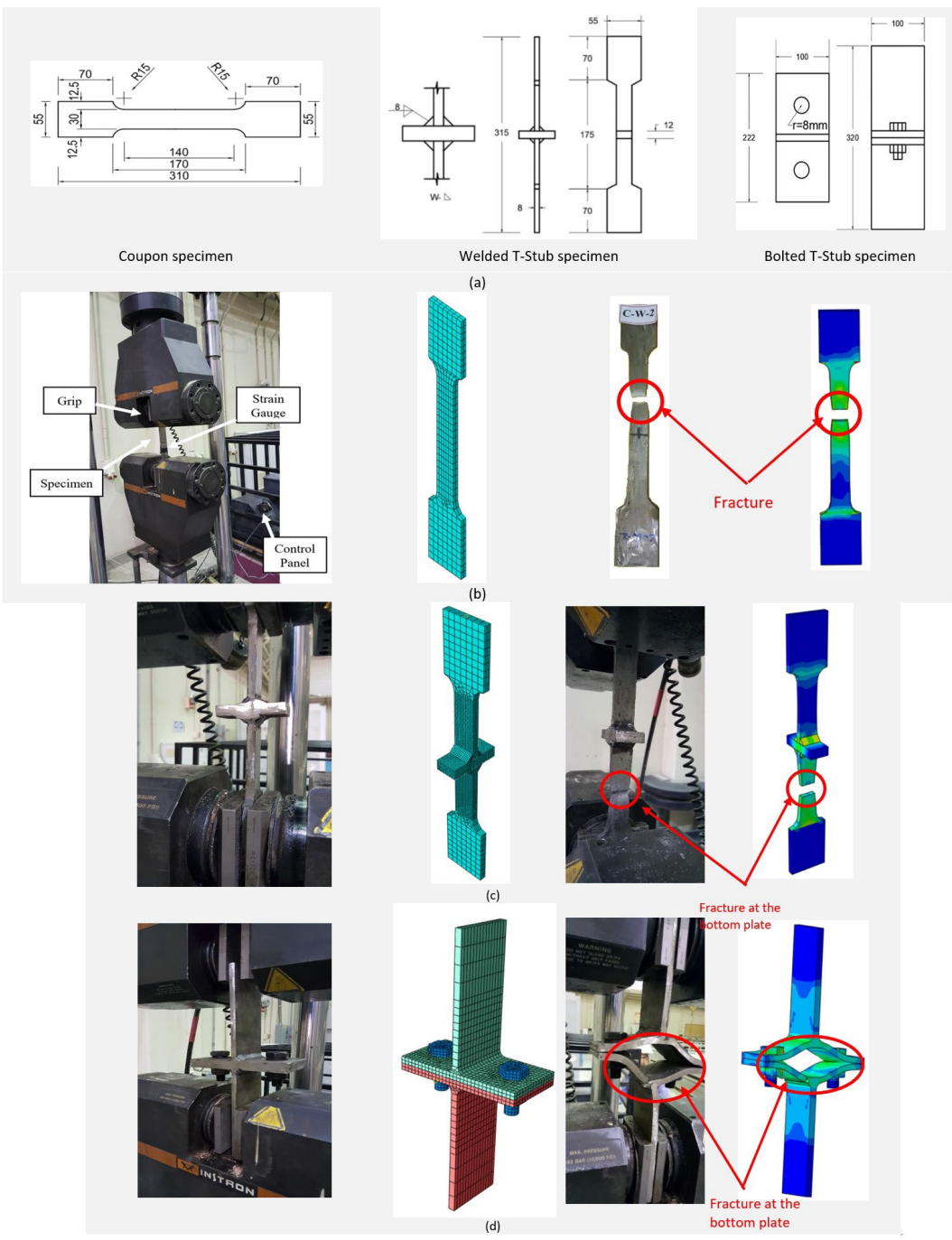

Figure 5: Details of material specimens used for FE validation: (a) Detailed size diagrams of the specimens; (b) Coupon test; (c) Welded T-Stub test.; (d) Bolted T-Stub under test. 


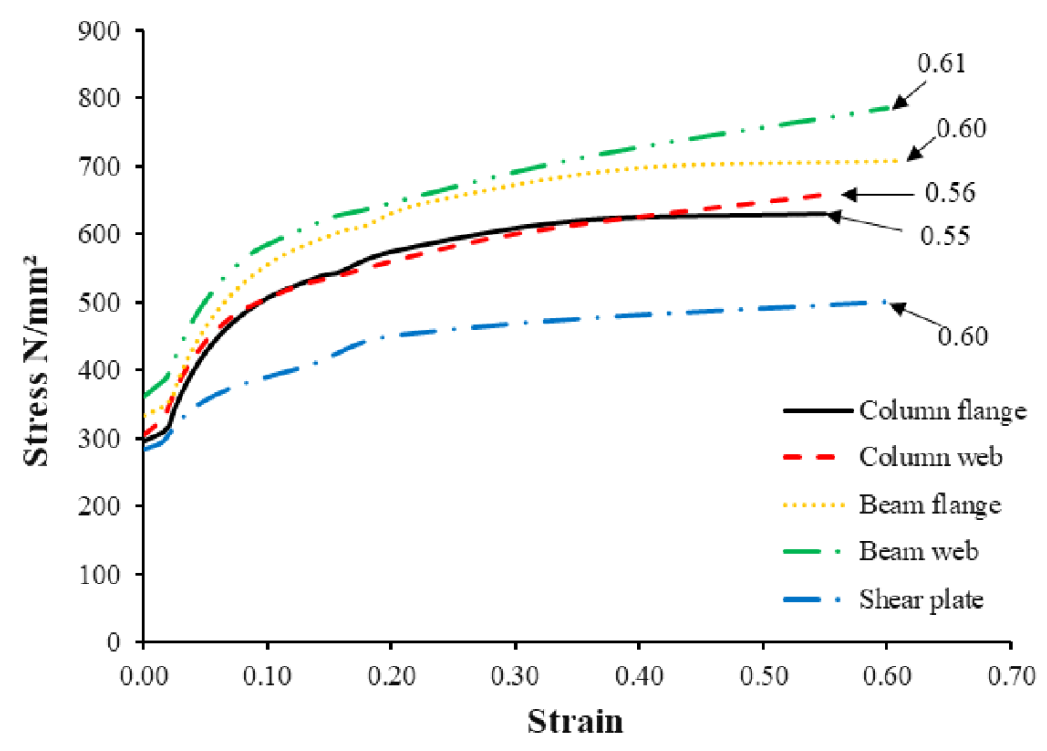

Figure 6: True stress vs plastic strain graph for coupon materials.

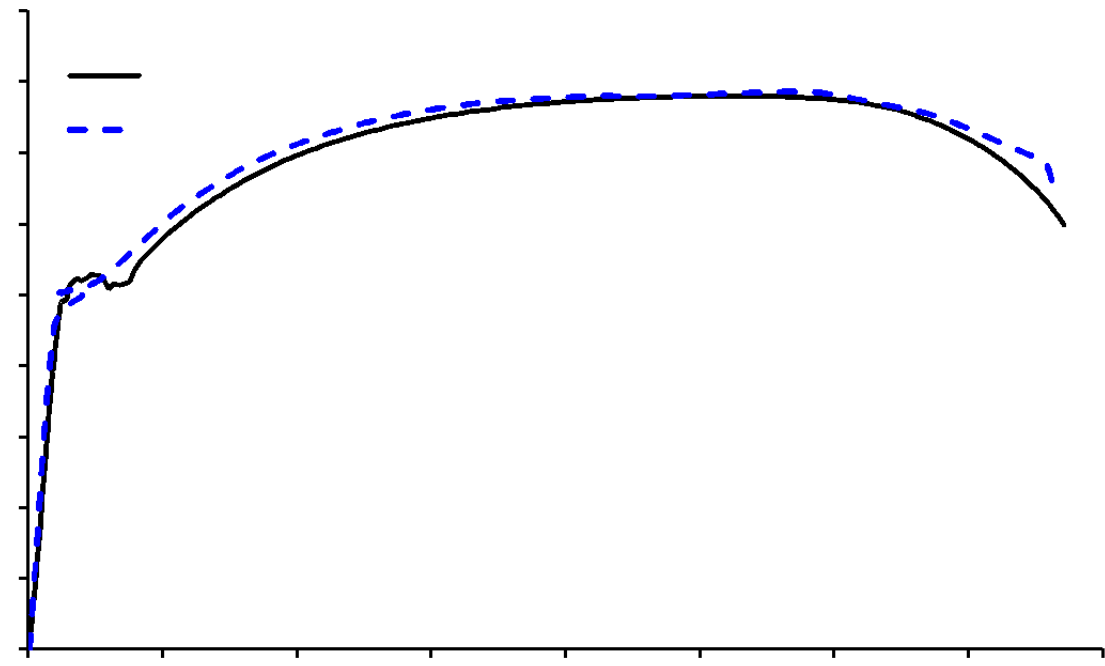

Figure 7: Comparison of load vs displacement response for one coupon plate specimen.

As a model for concrete, the concrete damage plasticity model (CDPM) was used in this work. To simulate the complex behavior of quasi-brittle materials like concrete, CDPM is often applied because of its adaptability and breadth of applications. Modeling concrete's behavior under monotonic and cyclic loads may be done through this model. In concrete, the nonlinear stress-strain responses reveal the material's pliability and damage response (Alhammadi, S. A.,2021). Given that few researchers have tested concrete under a variety of settings, failure envelopes were produced. CDPM is discussed in further detail in ABAQUS (2020). Table 4 shows data on dilation angle, eccentricity, stress ratio, shape factor, and viscosity parameter.

Shan et al. (2019) presented material models for masonry components based on a study of masonry walls, which were accepted, calibrated, and used in the current investigation. 3D-stress solid components were used to replicate masonry units, and the thickness of the mortar connection was halved for each masonry unit (2019). According to Shan et al. (2019), tensile or shear cracking between masonry units occurs when forces on the mortar connections are greater than the strength of the mortar connections. This study used zero-thickness cohesive pieces to model the behavior of mortar connections (2019). The "General Contact" module in ABAQUS was used to simulate the interactions 
between steel frames (beams and columns) and the masonry infill walls, as well as between masonry units once the mortar connections cracked (Shan et al.,2016). The friction coefficient of 0.45 represented the normal interaction using "Hard contact" and the tangential interaction using "Penalty formulation." Using the CDPM model, the compressive stress-strain relationship suggested by Kent-Scott-Park was used for the masonry units (Kent and Park, 1971; Scott et al., 1982). The masonry units' compressive strength ( $\mathrm{fcm}$ ) was estimated to be $12.8 \mathrm{MPa}$ on the basis of Ref. (Shan et al. (2019)). The masonry unit's residual compressive strength was considered to be $0.1 \mathrm{fcm}$. The values of 0.0022 and 0.0055 were assumed for the compressive strain at compressive strength $(\varepsilon \mathrm{cm})$ and the ultimate compressive strain at residual compressive strength (عum). A "tie" contact interface was used to imitate welds between various steel components (Alrubaidi et al.,2020).

\subsection{Mesh generation}

Figures 8 and 9 demonstrate the overall view of the numerical modeling of a one-story 2D test assembly, a shear beam-column connection, and infill walls. The FE mesh was generated using eight-node reduced integration solid elements for various frame components (beams, columns, bolts, shear plates, and masonry units) (Alrubaidi et al., 2020; Meng et al., 2018). The simulation in the FE model used solid components ranging from $2 \mathrm{~mm}$ to $25 \mathrm{~mm}$. Two-node linear 3D truss elements (T3D2) were used to generate the reinforcing bars (Rossi et al., 2020).

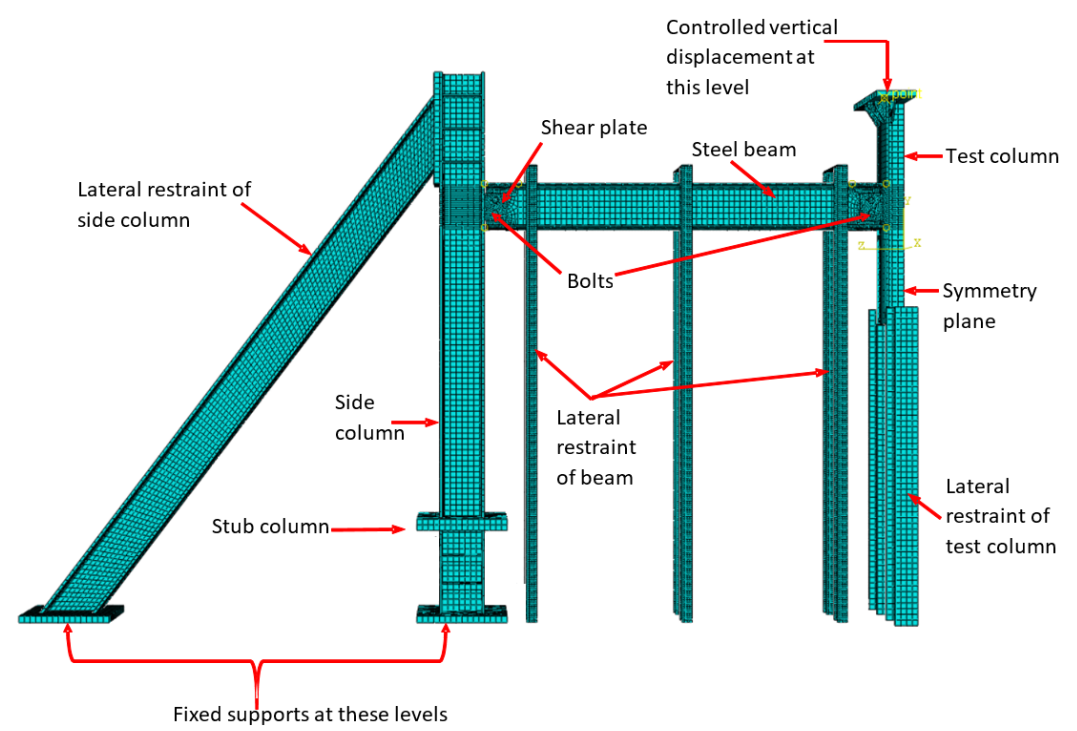

Figure 8: Overall view numerical modeling of one-story test assemblies.

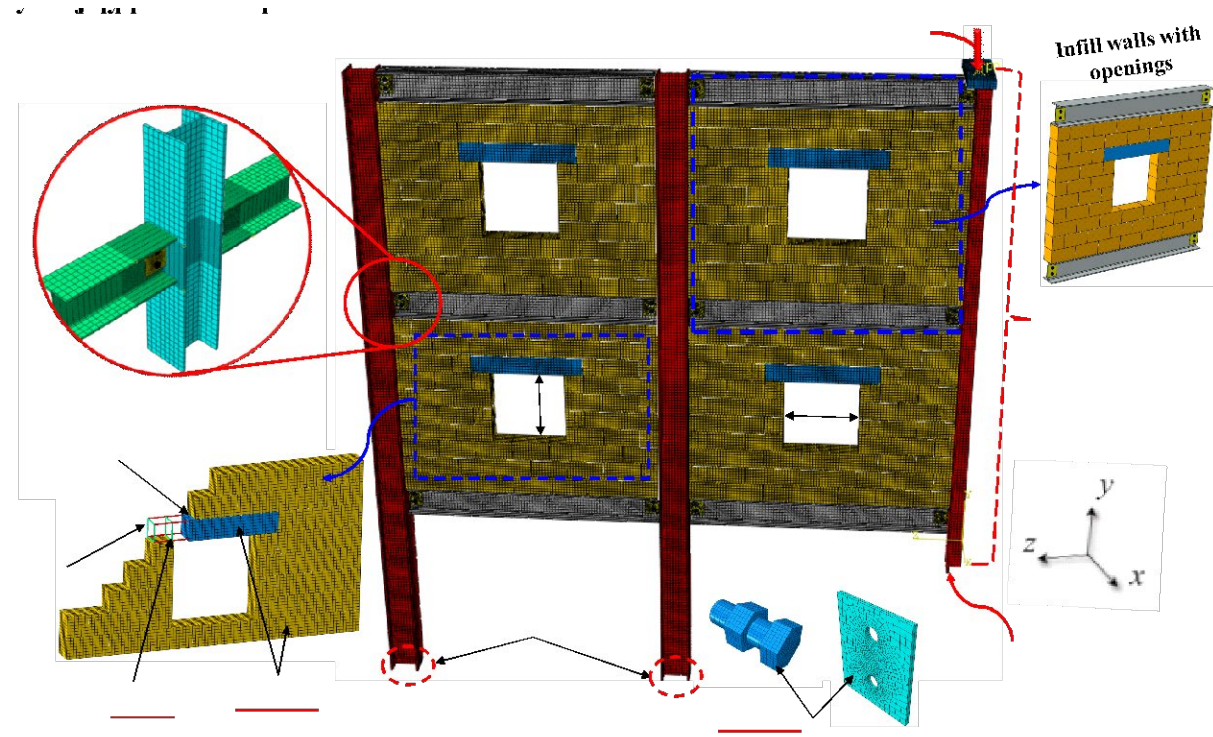

Figure 9: Modeling details of specimens with infill walls. 


\subsection{Loading and boundary conditions}

As shown in Figure 8, the boundary conditions for FE used for one-story 2D test assembly were closely matched to the boundary conditions of the test frames. Furthermore, the FE model incorporated lateral beam and column supports in the same places as the experiment. In regions where lateral supports were present, the out-of-plane movement of the beam flanges was prevented. Bottom nodes prevented displacement and rotation in all three dimensions ( $\mathrm{X}, \mathrm{Y}$, and $\mathrm{Z}$ ). In addition, the first-story columns of each frame in the FE infilled steel frame were controlled in all three dimensions $(X$, $\mathrm{Y}$, and $\mathrm{Z}$ ) to approximate strong foundations in existing buildings. Every node in the middle column of the model's symmetric plane was constrained to allow the y-directional translation only.

ABAQUS' explicit module was used to simulate a building's total collapse (Alrubaidi et al., 2020; Shan et al., 2019). Only half of the specimens are modeled because of the symmetry of the test frames, as seen in Figures 8 and 9 . Column top nodes received a displacement-time history to reflect the displacement-controlled loads applied during testing, where the displacement developed at a rate of $100 \mathrm{~mm} / \mathrm{s}$ to replicate the tests.

\subsection{FE model validation}

This research's experimental data (shear steel frame) and the study by Shan et al. (2019) on a single floor-infilled frame specimen were used to verify the FE models' accuracy. This verification is discussed in terms of load-displacement behavior and the failure mechanism that occurred in the FE study data. Table 2 compares the experimentally verified and numerically predicted main load-displacement results for the steel test frame. When the FE results were compared with the test results, minor discrepancies were observed because numerical modeling successfully predicted all cases.

Figure 3 depicts the numerically predicted failure mechanisms of the two test frames, which agree well with the results. The comparison of the observed (experimental) and anticipated (numerically) load versus the middle column displacement for the two test frames is shown in Figure 4. In addition, a high agreement was observed between the experimental and numerically expected curves, particularly for the maximum load. The stiffness of the test frames was numerically assessed over the entire response range compared with the experimental tests, as shown in Figure 4. The FE models predicted the descending component of the load-displacement response with high precision (Figure 4), thus demonstrating the accuracy of the constitutive modeling.

One of the validation tasks for the experimental specimens created in this study was to calibrate the shear connection between the beam and the column and how to perform it under progressive collapse. The study by Shan et al. (2019) was used to calibrate the infilled frame and its properties, as well as everything else related to it. Following the observation of congruence between the experimental and numerical studies, an expanded study with a parametric study that considers the effect of the walls as well as the influence of multiple frames and the number of stories in terms of the shear connection between the beam and the column was carried out.

\subsection{Models for the Parametric Analysis}

This study emphasizes the effectiveness of various infill walls on the progressive collapse performance of a steel structure with a shear beam-column connection. Thus, three major factors were proposed: the impact of multiple frames, the effect of the number of stories, and the influence of the walls for the steel shear frame in various instances.

Figure 10 depicts four different types of bare steel frames, each with its own special case. Figure 10a shows a single frame and the first case (S-1). For Figure 10b, S-2 shows a frame similar to S-1 but is composed of two stories, where the purpose of this case is to demonstrate the impact of the second story on the performance of the bare steel frames in the case of progressive collapse. For Figure 10c, S-3 shows whether the specimen consists of two stories and at the same time has two adjacent ones. S-4 in Figure 10d shows that a single steel frame has three stories. It also presents the extent of its impact in the event of a progressive collapse.

Figure 11 depicts the geometric dimensions and all the characteristics of the steel-infilled frames in all cases. All stories had a height of $1.5 \mathrm{~m}$. The span length of all the steel beams was $2 \mathrm{~m}$. The steel beam section was H $194 \mathrm{~mm} \times 150 \mathrm{~mm}$, while the steel column section was $\mathrm{H} 200 \mathrm{~mm} \times 200 \mathrm{~mm}$. The infill walls were constructed using solid concrete masonry blocks and mortar (Shan et al. (2019)). At the top of each opening in the walls, an RC beam was erected to support the higher concrete masonry blocks. Under middle steel column-loss situations, 16 types of infilled steel frames with shear beam-column connections were numerically analyzed in this section. Each of the 16 different steel frame designs can be seen in Figure 12 and Table 5. An approach similar to that used by codes and standards was used to create the specimens in this study (see Table 5). The parametric research focused on the impacts of the type of infill wall, infill arrangement, opening in the infill wall, opening size, opening position, and opening shape on the performance of the steel frames in the case of progressive collapse (Figure 12). Steel frame failure mechanism, load-displacement response (flexural and catenary action stages), beams' axial force, and horizontal displacement were evaluated to analyze these parameters. 
Table 5 Details of FE matrix for different types of steel frame

\begin{tabular}{|c|c|}
\hline Specimen ID & Infilled frame details \\
\hline & The effect of multiple frames and number of stories \\
\hline S-1 & One story with two-bay frame (see Figure 10a) \\
\hline S-2 & Two story with two-bay frame (see Figure 10b) \\
\hline S-3 & Two story with four-bay frame (see Figure 10c) \\
\hline \multirow[t]{2}{*}{ S-4 } & Three story with two-bay frame (see Figure 10d) \\
\hline & The effectiveness of various infill walls \\
\hline S-F-1 & Full infilled frame (see Figure 12a) \\
\hline S-F-2 & Bare frame (see Figure $12 b$ ) \\
\hline S-F-3 & Partial infilled frame - Lower story infilled and upper story bare (see Figure 12c) \\
\hline S-F-4 & Partial infilled frame - Lower story bare and upper story infilled (see Figure 12d) \\
\hline S-F-5 & Partial infilled frame - The two story next to the removed column are infilled (see Figure 12e) \\
\hline S-F-6 & Partial infilled frame - The two story next to the removed column are bare (see Figure 12f) \\
\hline S-F-7 & Infilled frame with openings (Lo = ho) (see Figure 12g) \\
\hline S-F-8 & Infilled frame with openings (Lo $=2 \mathrm{ho}$ ) (see Figure $12 \mathrm{~h}$ ) \\
\hline S-F-9 & Infilled frame with openings ( $2 \mathrm{Lo}=\mathrm{ho}$ ) (see Figure 12i) \\
\hline S-F-10 & Infilled frame with openings ( $2 \mathrm{Lo}=2 \mathrm{ho})$ (see Figure $12 \mathrm{j}$ ) \\
\hline S-F-11 & Half infilled frame for two story-Horizontal (see Figure 12k) \\
\hline S-F-12 & Half infilled frame for two story-Vertical (see Figure 12I) \\
\hline
\end{tabular}

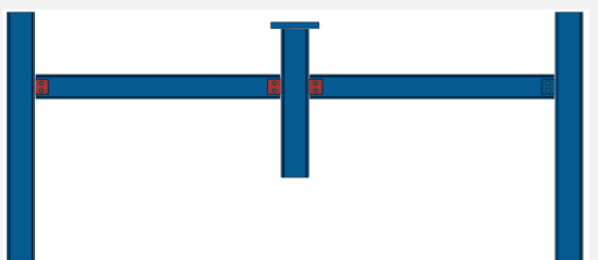

One story with two-bay frame

S-1

(a)

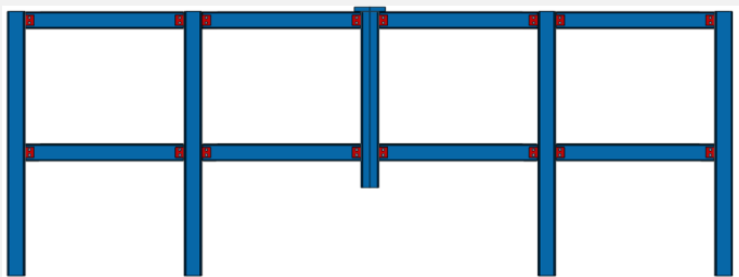

Two story with four-bay frame

S-3

(c)

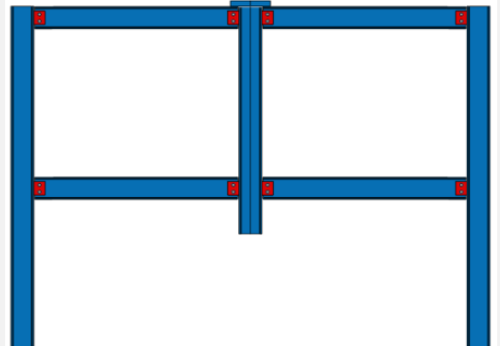

Two story with two-bay frame

S-2

(b)

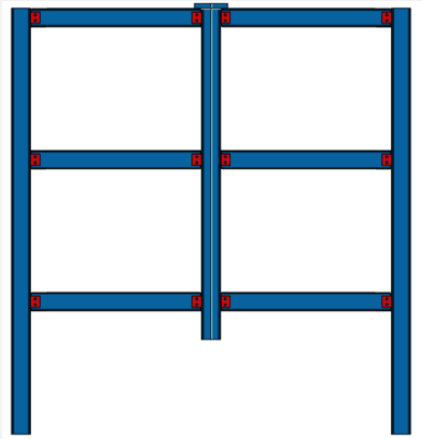

Three story with two-bay frame S-4

(d)

Figure 10: Details of steel frames with multiple frames and different number of stories. 


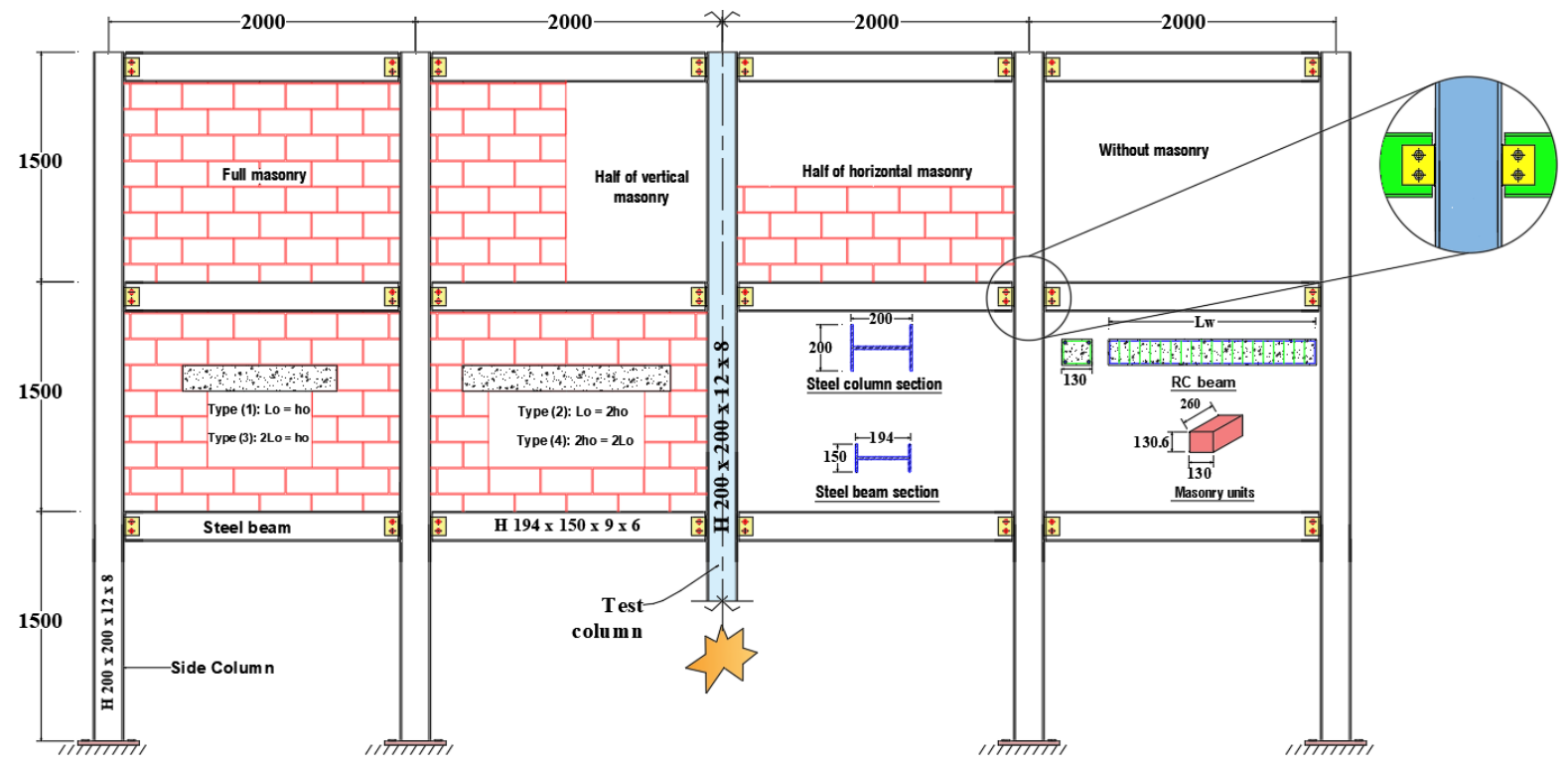

Figure 11: Test setup details for FE infilled steel frame (Dimensions are in $\mathrm{mm}$ ).
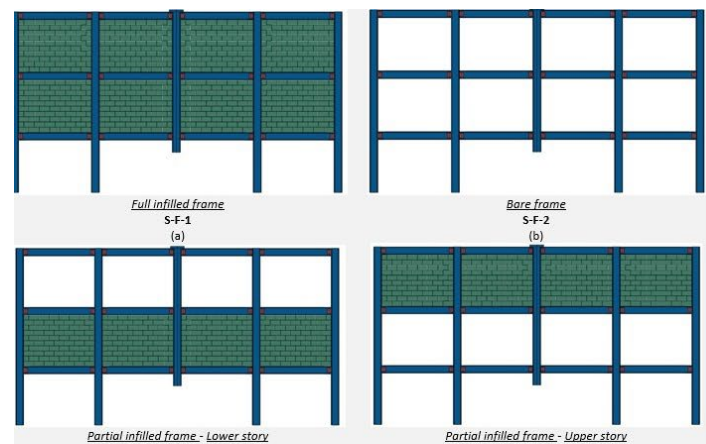

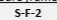
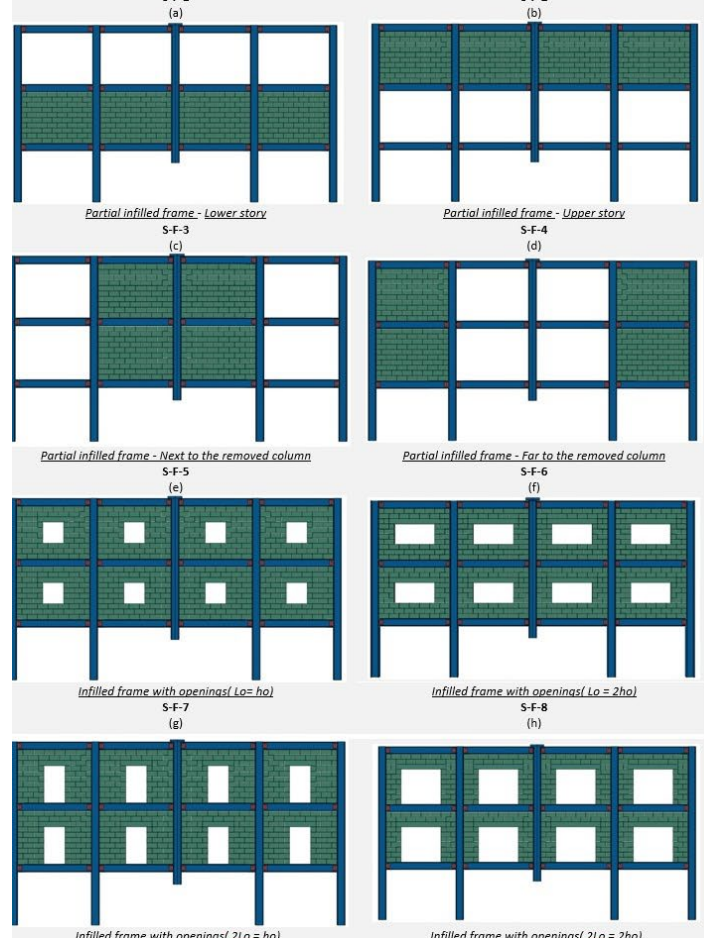

$\underset{\substack{s+8 \\ \text { (h) }}}{\substack{n \\(n)}}$
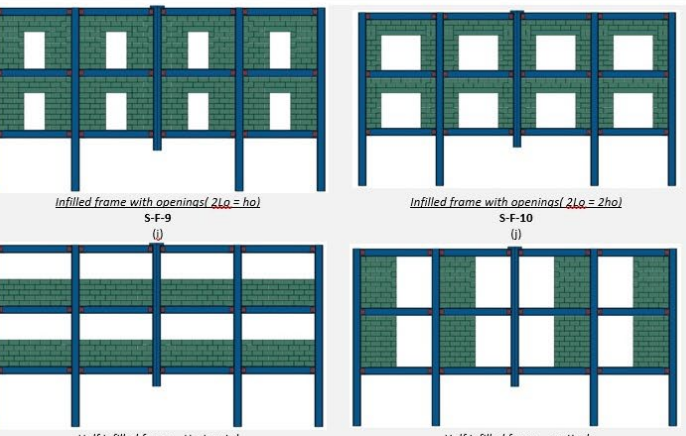

S-F-12
(I)

Figure 12: Details of all prototype steel infilled frames. 


\section{NUMERICAL INVESTIGATION OF DIFFERENT STEEL FRAMES}

\subsection{Effects of multiple of frames and stories}

Based on the S-1 steel frame, a single-story reference steel frame is depicted in Figure 10a. As previously stated, given the type of beam-column connection and the lack of continuity of the frame next to it, as well as its isolation with only one floor, this steel frame was progressively collapsing. The mode of failure of the four specimens, which differed in the number of frames and stories but were unified in the type of connection between the beam and the column, is shown in Figure 13. In addition, the type of collapse was unified in all four specimens, which was the failure of the shear plate connecting the column and the beam. The load and displacement results for the four specimens shown in Figure 14 indicate that the specimen S-2, which was similar in design to the first specimen (S-1), performed similarly to the first specimen (S-1) in the initial stage to the extent of displacement of the middle column, $200 \mathrm{~mm}$. The displacement was one and a half times the depth of the beam, and this performance was similar to all four specimens (see Figure 14). Afterward, the resistance to the progressive collapse started to rise, and a large axial force started to build up in the beams. Thus, the second story started to have an effect. It reached $186 \mathrm{kN}$ for the first story and $146 \mathrm{kN}$ for the second. The peak load was $193 \mathrm{kN}$ at $570 \mathrm{~mm}$, which was 2.7 times as much as that of the S-1 specimen.

Specimen S-3 had a similar design to specimen S-1 but had two stories and two frames adjacent to the middle frame. The performance of S-3 in terms of load and displacement was similar to that of the second specimen S-2, which differed in terms of the number of frames where the results of load and displacement were presented (Figure 14 and Table 6). Therefore, no effect, such as the effect of multiple stories, was observed in the adjacent frame. This outcome was due to the type of connection that worked to transfer and distribute loads from one frame to another, which was not done in the case of simple connections. As specimen S-3 had a maximum load of $210 \mathrm{kN}$ at a displacement of $637 \mathrm{~mm}$ (Figure 14), this force was considered 2.9 times greater than that of the reference specimen S-1 (Table 6).

Regarding the fourth specimen, S-4, which was a single frame and had three stories, the effect of the third story was not great when compared with the second specimen (S-2), thus confirming that the type of connection played an effective role. Given that specimen S-4 had a maximum load of $224 \mathrm{kN}$ at a displacement of $608 \mathrm{~mm}$ (Figure 14), the peak load was 3.1 times that of the reference specimen S-1 (Table 6). Thus, the number of stories and frames had a significant impact. However, this role could weaken due to the type of connection between the columns and beams, which worked to distribute the loads, increasing the overall resistance of the steel frame system in general.

Table 6 FE results for shear connections with varying number of frames and stories*

\begin{tabular}{|c|c|c|c|c|c|c|c|c|c|c|c|c|c|c|c|c|c|}
\hline \multirow[b]{2}{*}{$\begin{array}{l}\text { Specimen } \\
\text { ID }\end{array}$} & \multicolumn{4}{|c|}{ Flexural action stage } & \multicolumn{3}{|c|}{ Catenary action stage } & \multicolumn{3}{|c|}{ Peak beam axial force } & \multicolumn{3}{|c|}{$\begin{array}{c}\text { Max. Horizontal } \\
\text { displacement (mm) }\end{array}$} & \multicolumn{4}{|c|}{ Total frame capacity } \\
\hline & $\begin{array}{c}\mathrm{Py} \\
(\mathrm{kN})\end{array}$ & $\begin{array}{c}\text { Äy } \\
(\mathrm{mm})\end{array}$ & $\begin{array}{l}\mathrm{Pu}, \mathrm{FA} \\
(\mathrm{kN})\end{array}$ & $\begin{array}{c}\ddot{A} u, c-F A \\
(m m)\end{array}$ & $\begin{array}{c}\mathrm{Pu}, \mathrm{CA} \\
(\mathrm{kN})\end{array}$ & $\begin{array}{c}\mathrm{Pu}, \mathrm{CA} \\
/ \\
\mathrm{Pu}, \mathrm{FA}\end{array}$ & $\begin{array}{c}\text { Äu,c- } \\
\text { CA } \\
(\mathrm{mm})\end{array}$ & $\begin{array}{c}\text { F1- } \\
\mathrm{Nu}, \mathrm{CA} \\
(\mathrm{kN})\end{array}$ & $\begin{array}{c}\mathrm{F} 2- \\
\mathrm{Nu}, \mathrm{CA} \\
(\mathrm{kN})\end{array}$ & $\begin{array}{c}\text { F3- } \\
\mathrm{Nu}, \mathrm{CA} \\
(\mathrm{kN})\end{array}$ & $\begin{array}{l}\text { First } \\
\text { floor }\end{array}$ & $\begin{array}{l}\text { Second } \\
\text { floor }\end{array}$ & $\begin{array}{l}\text { Third } \\
\text { Floor }\end{array}$ & $\begin{array}{c}\mathrm{Pu} \\
(\mathrm{kN})\end{array}$ & $\begin{array}{c}\ddot{A} u \\
(\mathrm{~mm})\end{array}$ & $\begin{array}{c}\mathrm{Eu} \\
(\mathrm{kN} \cdot \mathrm{m})\end{array}$ & $\begin{array}{l}\mathrm{Pu} / \mathrm{Pu}, \\
\mathrm{S}-1\end{array}$ \\
\hline S-1 & - & - & 9 & 92 & 72 & 8.0 & 383 & 172 & - & - & 16 & - & - & 72 & 391 & 12.5 & - \\
\hline $\mathrm{S}-2$ & - & - & 10 & 86 & 193 & 19.3 & 473 & 184 & 146 & - & 75 & 17 & - & 193 & 570 & 49 & 2.7 \\
\hline S-3 & - & - & 12 & 87 & 210 & 17.5 & 505 & 187 & 148 & - & 36 & 98 & - & 210 & 637 & 57 & 2.9 \\
\hline S-4 & - & - & 12 & 102 & 224 & 18.6 & 480 & 190 & 157 & 150 & 31 & 79 & 138 & 224 & 608 & 63 & 3.1 \\
\hline
\end{tabular}

*Py $=$ load at first yield of beam bottom flange at inner column face; $\Delta y=$ displacement of middle column at first yield of beam bottom flange at inner column face; Pu,FA = peak load of flexural action stage; $\triangle \mathrm{u}, \mathrm{c}-\mathrm{FA}=$ displacement of middle column at peak load of flexural action stage; $\mathrm{Pu}, \mathrm{CA}=$ peak load of catenary action stage; $\Delta \mathrm{u}, \mathrm{C}-\mathrm{CA}=$ displacement of middle column at peak load of catenary action stage; Nu,CA = peak beam axial force at catenary action stage; $\mathrm{Pu}=$ progressive collapse resistance; $\Delta \mathrm{u}=$ displacement of middle column at ultimate state; and Eu = energy dissipated at ultimate state. 


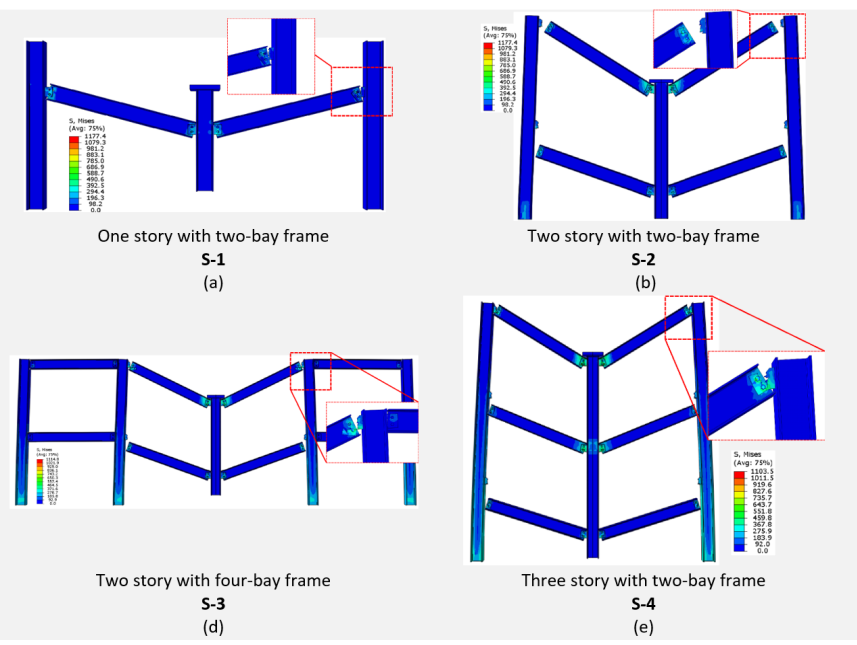

Figure 13: FE mode of failure for of steel frames with multiple frames and different number of stories.

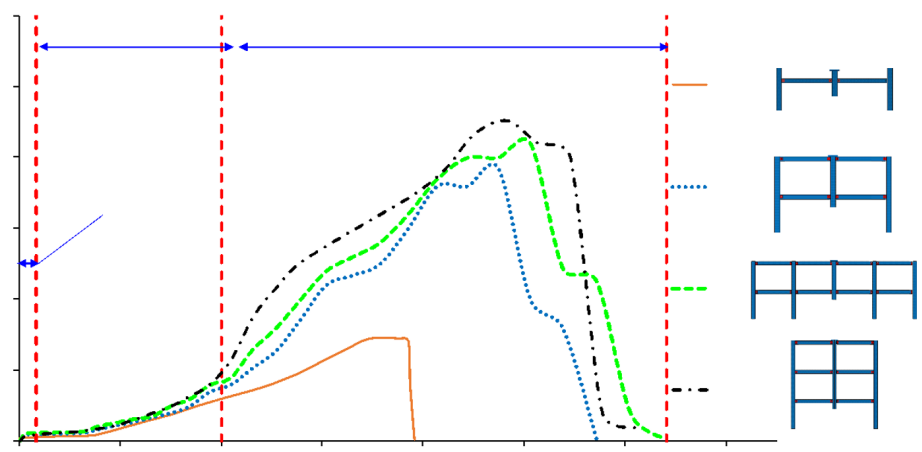

Figure 14: Comparison of FE load-displacement curves for of steel frames with multiple frames and different number of stories.

\subsection{Effects of infill wall}

The failure modes of the complete infilled, partial infilled, and bare frame assemblies are all shown in detail in Figure 15. A substantial portion of the resistance came from the walls, as illustrated in Figures $15 \mathrm{a}, 15 \mathrm{~b}$. When the shear connection failed, everything above it from a wall would collapse (Figures 15a, 15b)), thus leading to an incredibly excellent resistance pattern compared with the bare steel frame (Figures 15a, 15b). Figure 16 presents the axial tensile force that was mobilized in the beams of all assemblies. Phases of progressive collapse for FE load-displacement curves included the initial stage, the flexural action stage (FA), and the catenary action stage (CA). These specimens' load-displacement characteristics are presented in Table 7 and Figures 16-20. The fully filled wall of shear connections improved the overall frame capacity by $294 \%$, thus indicating that the walls had great resistance to progressive collapse, particularly when the wall was totally solid, as in sample S-F-1.

The evolution of axial loads along steel beams in three floors is seen in Figure 16. In both infilled (S-F-1) and bare (S-F-2) frames, the first-floor steel beam above the removed steel column developed significant axial force (F1-Nu, CA) compression prior to the center steel column displacement of $200 \mathrm{~mm}$ (1.5 db of the beam). Then, it developed axial tension force until failure, thus indicating the sequential mobilization of the compressive arch and the catenary action. In comparison, the axial load on the second and third story beams (F2-Nu, CA and F3-Nu, CA) was low, and the beam was mostly flexural in case (Table 7). This difference was due to first-floor steel beams having greater boundary limitations than second- and third-floor steel beams. When the entire infilled frame was compared with bare frames, the catenary action stage was fully triggered, thus resulting in a $394 \%$ increase in progressive collapse resistance (Table 7).

The horizontal displacements of all assemblies at outside columns on the three stories are shown in Figures 17 compared with the vertical displacement curves. The negative and positive values corresponded to displacements inward (laterally approaching the center steel column) and outward (laterally receding from the main steel column). As the vertical displacement increased, the catenary action in the steel beams led the beam-column connections of the bare frame (S-F-1) to slide inward progressively, as depicted in Figure 17. Given the connection failure, the tension forces in beams were decreased. Thus, vertical displacements considerably minimized the inward displacements of the first-story connection (Table 7). From the start of the first step, the beam-column connections on the bare frame slid inward. In 
contrast to those that migrated outward throughout the initial and plastic stages until they reached their maximum values, full-filled frames migrated inward after the catenary stage. This inward migration was due to the strut effect of masonry infill walls (Table 7). In accordance with Figure 18, the reduction in the peak load for the bare frame (S-F-1) with shear beam-column connection was in the range of $75 \%$ compared with the full infilled frame (S-F-2).

Table 7 Summary of FE results for shear connections with different infilled frame *

\begin{tabular}{|c|c|c|c|c|c|c|c|c|c|c|c|c|c|c|c|c|c|}
\hline \multirow[b]{2}{*}{ Specimen ID } & \multicolumn{4}{|c|}{ Flexural action stage } & \multicolumn{3}{|c|}{ Catenary action stage } & \multicolumn{3}{|c|}{ Peak beam axial force } & \multicolumn{3}{|c|}{$\begin{array}{c}\text { Max. Horizontal } \\
\text { displacement }(\mathrm{mm})\end{array}$} & \multicolumn{4}{|c|}{ Total frame capacity } \\
\hline & $\begin{array}{c}\text { Py } \\
(\mathrm{kN})\end{array}$ & $\begin{array}{c}\ddot{A} y \\
(\mathrm{~mm})\end{array}$ & $\begin{array}{c}\mathrm{Pu}, \mathrm{FA} \\
(\mathrm{kN})\end{array}$ & $\begin{array}{c}\text { Äu,c- } \\
\text { FA } \\
(\mathrm{mm})\end{array}$ & $\begin{array}{c}\mathrm{Pu}, \mathrm{CA} \\
(\mathrm{kN})\end{array}$ & $\begin{array}{c}\mathrm{Pu}, \mathrm{CA} \\
/ \\
\mathrm{Pu}, \mathrm{FA}\end{array}$ & $\begin{array}{c}\ddot{A} u, c-C A \\
(\mathrm{~mm})\end{array}$ & $\begin{array}{c}\mathrm{F} 1- \\
\mathrm{Nu}, \mathrm{CA} \\
(\mathrm{kN})\end{array}$ & $\begin{array}{c}\text { F2- } \\
\mathrm{Nu}, \mathrm{CA} \\
(\mathrm{kN})\end{array}$ & $\begin{array}{c}\mathrm{F} 3- \\
\mathrm{Nu}, \mathrm{CA} \\
(\mathrm{kN})\end{array}$ & $\begin{array}{l}\text { First } \\
\text { floor }\end{array}$ & $\begin{array}{l}\text { Second } \\
\text { floor }\end{array}$ & $\begin{array}{l}\text { Third } \\
\text { Floor }\end{array}$ & $\begin{array}{c}\mathrm{Pu} \\
(\mathrm{kN})\end{array}$ & $\begin{array}{c}\ddot{A u} \\
(\mathrm{~mm})\end{array}$ & $\begin{array}{c}\mathrm{Eu} \\
(\mathrm{kN} \cdot \mathrm{m}\end{array}$ & $\begin{array}{l}\mathrm{Pu} / \mathrm{Pu}, \\
\mathrm{P}-\mathrm{T}-2-\mathrm{S}\end{array}$ \\
\hline S-F-1 & - & - & 104 & 64 & 891 & 9 & 324 & 750 & 1167 & 56 & 3.3 & 21 & 49 & 891 & 625 & 330 & 3.94 \\
\hline S-F-2 & - & - & 9 & 92 & 226 & 25 & 483 & 190 & 157 & 150 & 30 & 82 & 146 & 226 & 609 & 63 & - \\
\hline S-F-3 & - & - & 102 & 86 & 424 & 4 & 392 & 796 & 140 & 229 & 20 & 67 & 131 & 424 & 650 & 149 & 1.87 \\
\hline S-F-4 & - & - & 117 & 86 & 605 & 5 & 435 & 221 & 1093 & 67 & 16 & 57 & 109 & 605 & 660 & 215 & 2.67 \\
\hline S-F-5 & - & - & 138 & 63 & 816 & 6 & 298 & 1154 & 743 & 81 & 18 & 64 & 116 & 816 & 634 & 308 & 3.61 \\
\hline S-F-6 & - & - & 9 & 92 & 238 & 26 & 497 & 220 & 181 & 209 & 27 & 86 & 148 & 238 & 561 & 57 & 1.05 \\
\hline S-F-7 & - & - & 93 & 53 & 695 & 7 & 256 & 772 & 772 & 94 & 21 & 70 & 132 & 695 & 680 & 271 & 3.07 \\
\hline S-F-8 & - & - & 104 & 54 & 519 & 5 & 272 & 435 & 480 & 143 & 16 & 55 & 103 & 519 & 624 & 217 & 2.29 \\
\hline S-F-9 & - & - & 110 & 76 & 614 & 6 & 335 & 474 & 504 & 93 & 20 & 64 & 120 & 614 & 620 & 220 & 2.71 \\
\hline S-F-10 & - & - & 87 & 64 & 406 & 5 & 422 & 302 & 212 & 144 & 21 & 69 & 121 & 406 & 619 & 169 & 1.79 \\
\hline S-F-11 & - & - & 62 & 92 & 256 & 4 & 551 & 223 & 208 & 169 & 24 & 72 & 133 & 256 & 621 & 79 & 1.13 \\
\hline S-F-12 & - & - & 103 & 83 & 370 & 4 & 335 & 310 & 132 & 143 & 20 & 65 & 118 & 370 & 620 & 126 & 1.63 \\
\hline
\end{tabular}

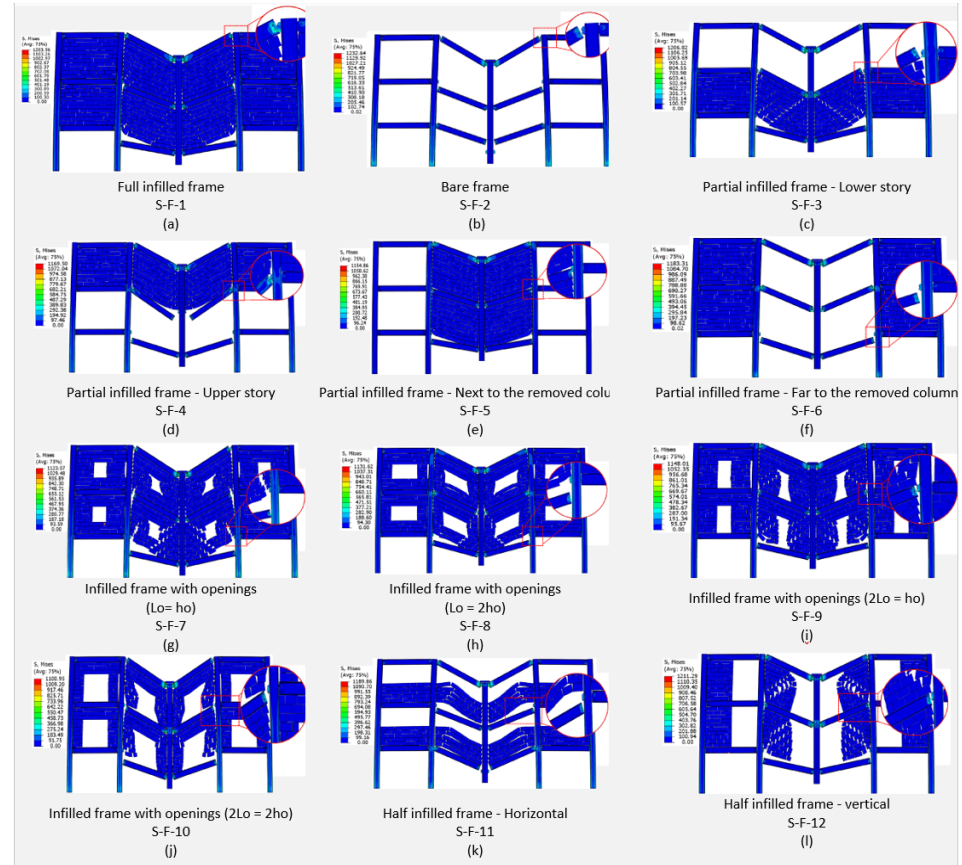

Figure 15: FE mode of failure for different types of steel infilled frames. 


\subsection{Effects of the partial infill wall arrangement}

To investigate the effect of the location of the infill wall in relation to the removed center steel column on the progressive collapse, partial infill walls were placed in vertical and horizontal rows. In Figure 12, prototype steel frames S-F-3 to S-F-6 were used to study the effect and behavior of the infill wall arrangement, with the following details: partial infilled frame - lower story (S-F-3), partial infilled frame - upper story (S-F-4), partial infilled frame - next to the removed column (S-F-5), and partial infilled frame - far away from the removed column (S-F-6). The results from prototype steel frames S-F-3 to S-F-6 were compared with the results from the full infilled frame (S-F-1). According to the findings, horizontal infill wall placement in the upper rows (S-F-4) outperformed the horizontal infill wall placement in the lower rows (S-F-3). The placement of infill walls in vertical rows closer to the removed column (S-F-5) resulted in the best frame performance across all infill wall arrangements. The performance of S-F- 5 was comparable with that of S-F-1, which was a fully infilled frame. Table 7 present a summary of FE results for all steel frames, in terms of load displacement, axial force of beams, and horizontal displacement. As shown in Figure 20, the permanent total frame capacity for S-F-3, S-F-4, S-F-5, and S-F-6 decreased by $52 \%, 32 \%, 8.0 \%$, and $73 \%$, respectively, compared with the full infill wall steel frame (S-F- 1 ).

\subsection{Effects of the opening in infill wall}

As shown in Figure 12, the parametric research compared models with different design factors in terms of the opening's size, location, and geometry, as demonstrated (prototype frames S-F-7 to S-F-12). The purpose of this experiment was to test the influence of the infill wall opening on the steel frame's load-bearing capability.

\section{Size Effects}

The previously stated validated numerical modeling technique was developed to explore the effect of different opening widths on the performance of infill walls. Prototype steel frames in S-F-7, S-F-8, S-F-9, and S-F-10 (Figure 12) with central opening ratios of $8 \%(\mathrm{LO}=\mathrm{ho}), 16 \%(\mathrm{LO}=2 \mathrm{ho}), 16 \%(2 \mathrm{LO}=\mathrm{ho})$, and $32 \%(2 \mathrm{LO}=2 \mathrm{ho})$, respectively, were tested. Lo is the length of the opening, and ho is its height. In addition, the opening ratio was considered. As opening size increased, the stiffness decreased in contrast to the infield frame as the resisting force decreased and displacement increased. A comparison of the peak load characteristics of the infield walls to those of the bare frame (S-F-2) is shown in Table 7. The percentage increase for models with openings in S-F-7, S-F-8, S-F-9, and S-F-10 compared with bare frame (S-F-2) ranged from $79 \%$ to $207 \%$ (Table 7).

As demonstrated in Figure 18, the permanent total frame capacity for S-F-7, S-F-8, S-F-9, and S-F-10 reduced by $22 \%, 42 \%$, $31 \%$, and $54 \%$, respectively, compared with the complete infill wall steel frame (S-F-1). The S-F-8 model had a $10 \%$ influence over the S-F-9 model, which varied in terms of the opening in its length from horizontal to vertical (Figure 18).

\section{Placement effects}

The openings in the wall may be put in a variety of positions based on the needs of the architectural design component. Although these diverse locations may meet the aesthetic demands of the architectural aspect, they may have other consequences on the structural aspect of the structure. Thus, in the event of a progressive collapse under a column-loss scenario, the variables that occur for steel frames owing to design requirements in the walls may be analyzed. The positioning of apertures is critical because it can affect the load routes inside the wall. The results of the prototype steel frames in Figure 12g-i were compared to investigate the effect of the opening position.

According to failure mechanisms and load-displacement system characteristics, the S-F-7 frame performed the best among the prototypes (S-F-7 to S-F-12). Steel frame FE failure modes are shown in Figures 15g-i. Table 7 compares the infield walls' peak loaddisplacement characteristics with those of the bare frame (S-F-2) (Pu). Between $13 \%$ and $207 \%$, the performance of prototype frames (S-F-7 to S-F-12) with different opening locations was observed (Table 7). Steel frames with openings performed better than bare steel frames when increasing the total frame capacity of the steel frame, even if they varied in the location of the openings.

\section{Shape effects}

Some of the most often used openings of different forms are discussed here. The efficiency of door and window openings were tested using prototype steel frames S-F-7 to S-F-10 with an opening ratio ranging from $16 \%$ to $32 \%$. Results from these facts indicated that the door opening could carry less load than the window opening can. Using half-length horizontal and high vertical opening prototype steel frames (Figures 18, 19 and 20), the results were compared. The masonry wall of prototype steel frame $\mathrm{S}-\mathrm{F}-11$ was at the bottom of the steel frame. The brick wall was positioned vertically to the left of the column to be removed in prototype frame S-F-12. As illustrated in Figure 18, when the openings on prototype steel frames were 50\%, the horizontal openings had a bigger influence on the steel frame bearing capacity than the steel frame with a complete wall. The flexural strength and stiffness of the S-F-12 prototype frame were higher than those of the S-F-11 prototype frame. For prototype frames S-F-11 and S-F-12, the peak loads were $370 \mathrm{kN}$ and $256 \mathrm{kN}$, respectively. 


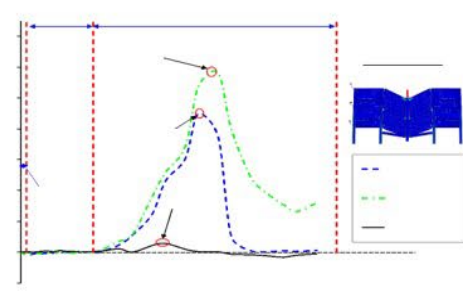

(a) Full infilled frame (S-F-1)

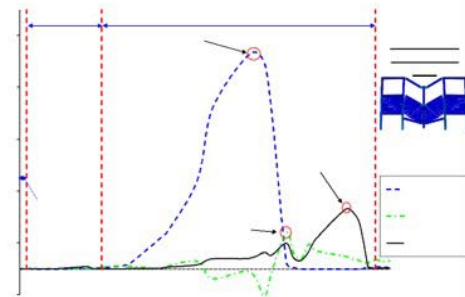

(c) Partial infilled frame - Lower story (S-F-3)

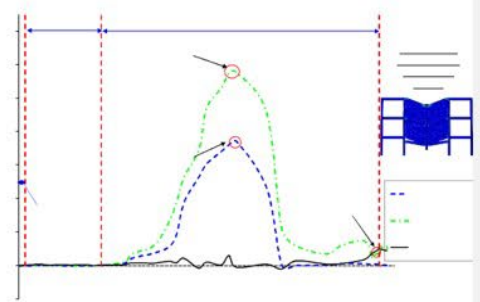

(e) Partial infilled frame - Next to the removed column (S-F-5)

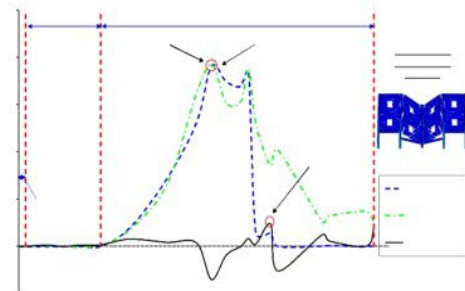

(g) Infilled frame with openings (Lo= ho) - ( S-F-7)

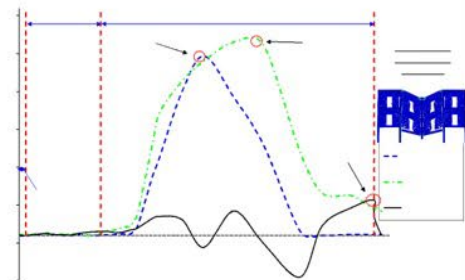

(i) Infilled frame with openings $(2 \mathrm{LO}=\mathrm{ho})-(\mathrm{S}-\mathrm{F}-\mathrm{g})$

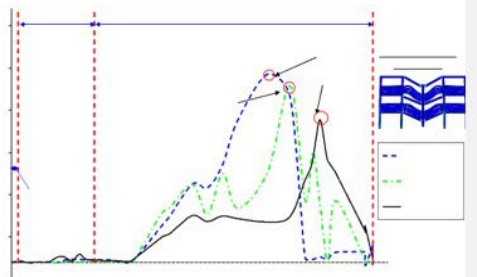

(k) Half infilled frame - Horizontal (S-F-11)

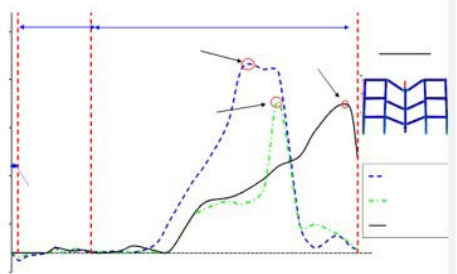

(b) Bare frame (S-F-2)

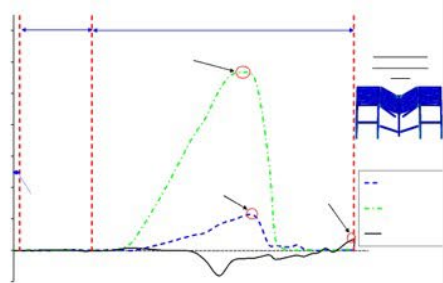

(d) Partial infilled frame - Upper story (S-F-4)

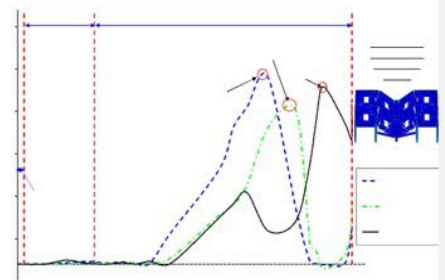

(f) Partial infilled frame - Far to the removed column (S-F-6)

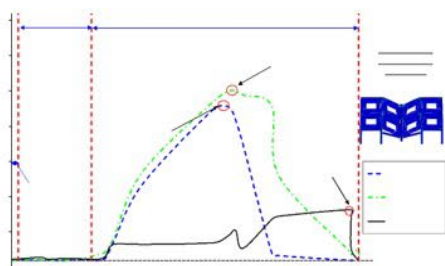

(h) Infilled frame with openings ( $L O=2 h 0)-(S-F-8)$

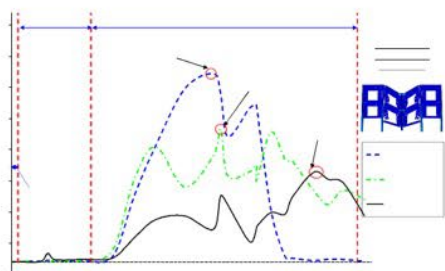

(j) Infilled frame with openings $(2 L \mathrm{~L}=2 \mathrm{ho})-(\mathrm{S}-\mathrm{F}-10)$

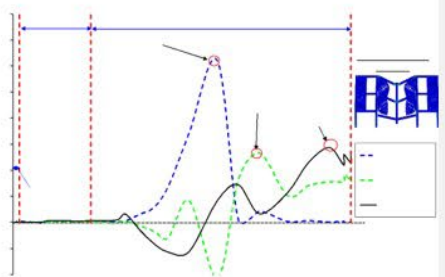

(I) Half infilled frame - vertical (S-F-12)

Figure 16: Axial forces mobilized in beams above the removed column for different types of steel infilled frames. 


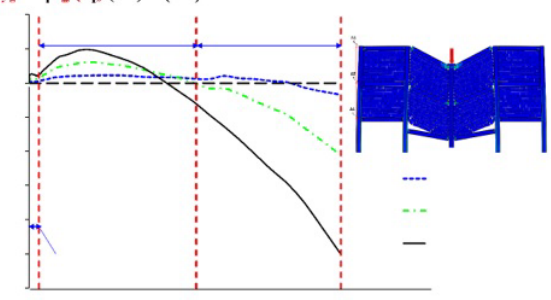

(a) Full infilled frame (S-F-1)

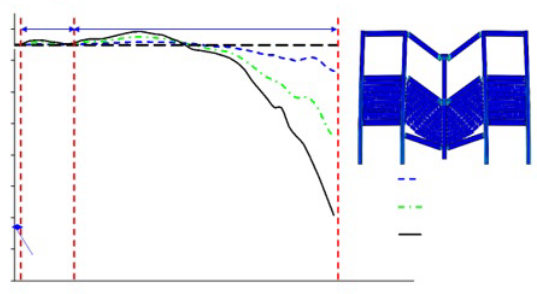

(c) Partial infilled frame - Lower story (S-F-3)

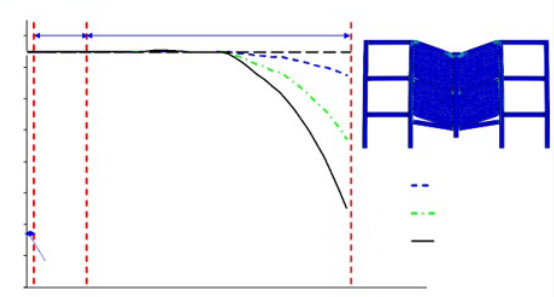

(e) Partial infilled frame - Next to the removed column (S-F-5)

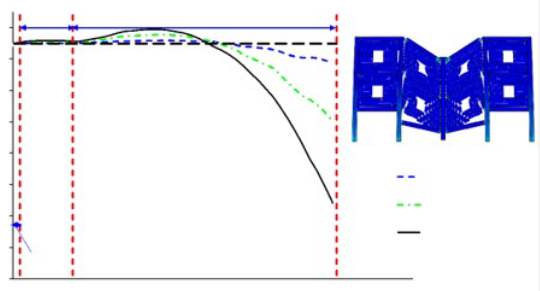

(g) Infilled frame with openings (Lo= ho) - (S-F-7)

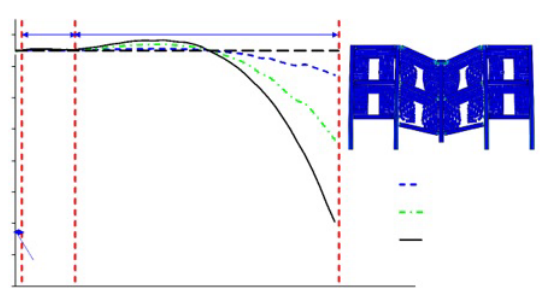

(i) Infilled frame with openings (2Lo $=$ ho $)-(S-F-9)$

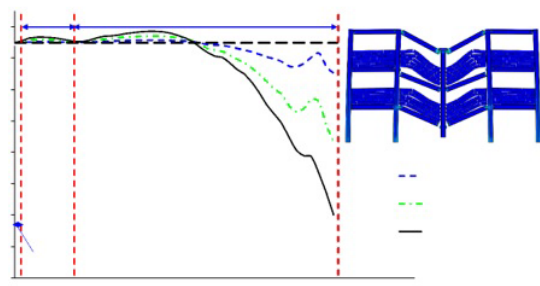

(k) Half infilled frame - Horizontal (S-F-11)

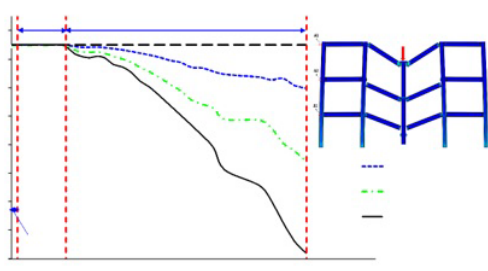

(b) Bare frame (S-F-2)

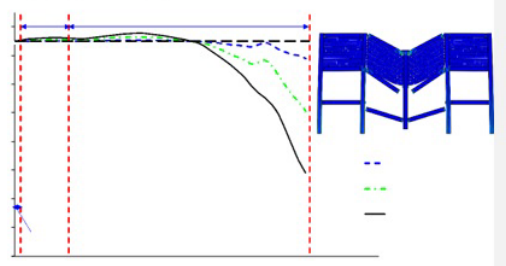

(d) Partial infilled frame - Upper story (S-F-4)

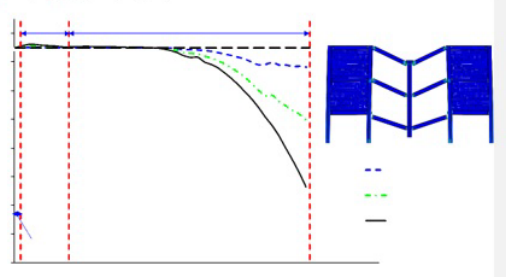

(f) Partial infilled frame - Far to the removed column (S-F-6)

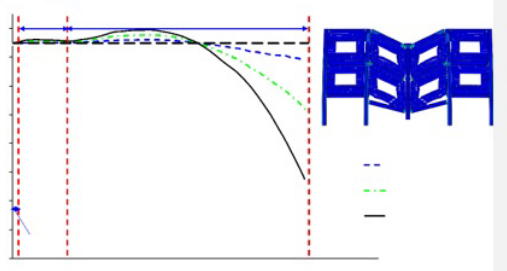

(h) Infilled frame with openings (Lo $=2 \mathrm{ho})-(\mathrm{S}-\mathrm{F}-8)$

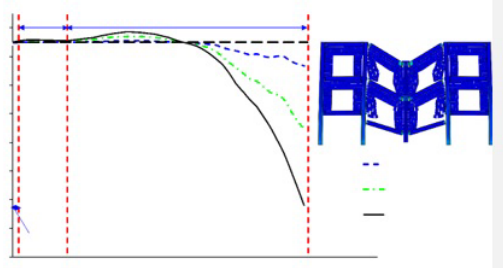

(j) Infilled frame with openings $(2 \mathrm{LO}=2 \mathrm{ho})-(\mathrm{S}-\mathrm{F}-10)$

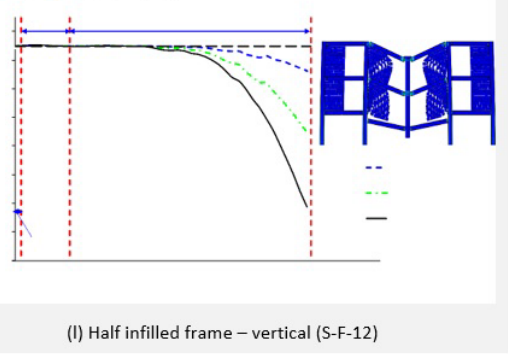

Figure 17: Horizontal displacement of steel frame specimens with shear connection under a middle column removal scenario (positive value indicates moving outwards and a negative value indicates moving inwards). 


\section{COMPARISON OF PROTOTYPE INFILL WALL STEEL FRAMES}

Table 7 indicates that for shear connections, axial load in steel beams (catenary actions) for a middle steel column-removing event can greatly increase progressive collapse resistance. If only the flexural action is considered, infilled steel frames with shear beam-column connections may achieve their maximum load resistance without the influence of catenary motion (Table 7).

Load-displacement comparisons for all types of prototype steel infilled frames are shown in Figures 18, 19 and 20. According to the results of the FE modeling, the researched prototype steel infilled frames passed through three different phases of performance (initial phase, flexural action phase, and catenary action phase). At modest displacement levels of the central column, all steel frames initially remained in the elastic area. When yielding occurred in the steel beam or shear plate at the inner beam-column connection, the second phase of reaction commenced, and the frames resisted loads by flexural action. The development of the catenary action stage was indicated by the creation of axial tensile loads in the frame beams as the displacement of the center column increased. Under catenary action, specimens S-F-1 and S-F-5 performed adequately. The failure mechanism (Figures 15 and 16) shows that the axial tensile load in the steel beam increased until the beam-column connection could no longer resist the combined axial and bending forces.

In Figure 20, all specimens are compared in terms of increasing collapse resistance (i.e., maximal force capacity) and energy wasted during the end phase. S-F-1 (full infilled steel frame) and S-F-5 (partial infilled steel frame - adjacent to the removed column) specimens had the strongest progressive collapse resistance among all prototype steel infilled or bare frames tested. Although the modes of failure were due to wall fracture caused by openings, the performance of specimens using an infilled frame with small openings was equivalent to that of a full infilled frame. Failure was ductile for specimens with an infilled frame with large openings or a partial infill wall arrangement (S-F-4, S-F-6, S-F-11, and S-F-12). The reasons for such failure were ultimately connected to the beam-column connection.

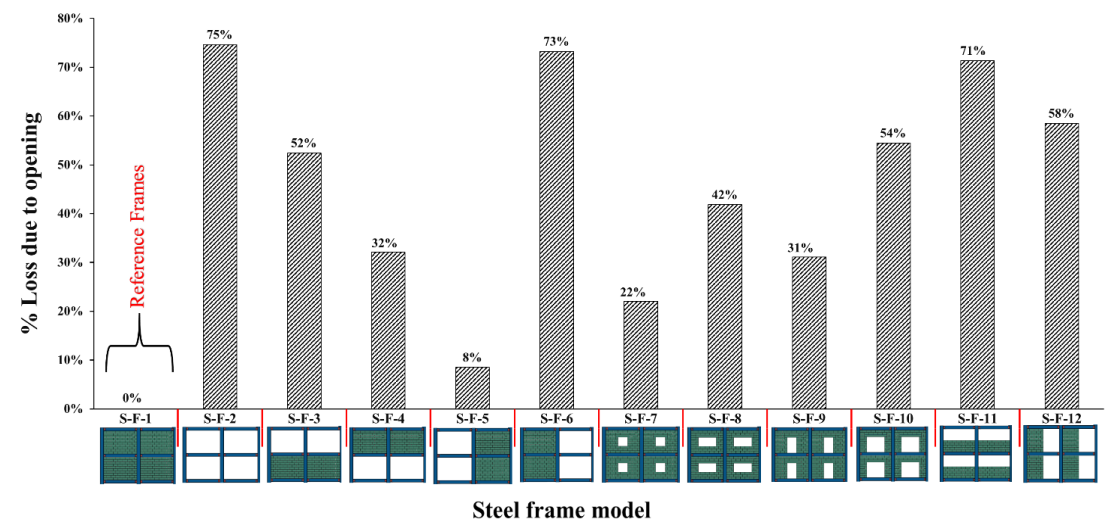

Figure 18: Effect of types of steel frame on performance of shear beam column connections.

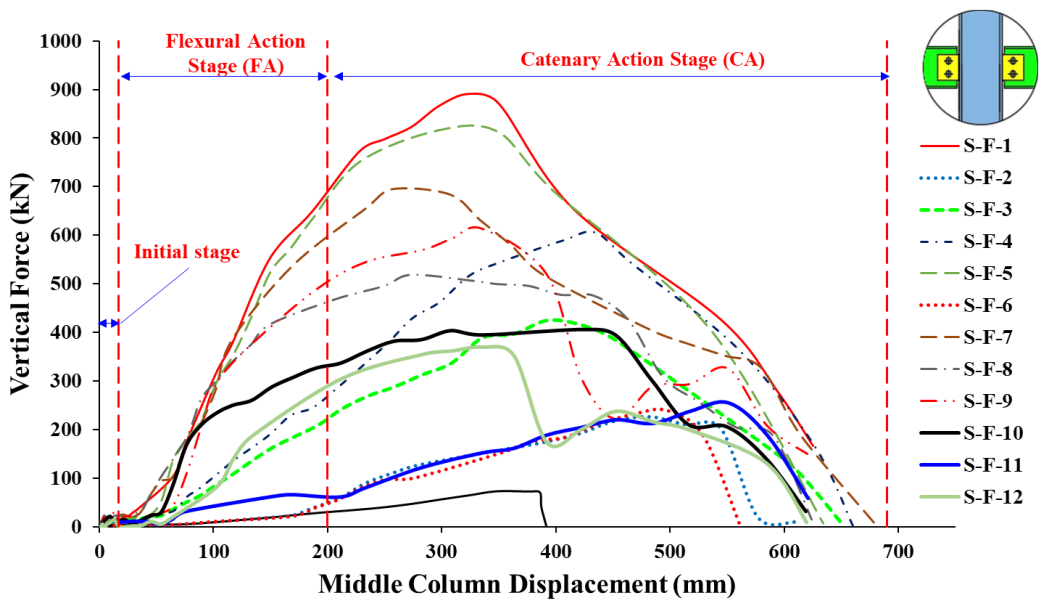

Figure 19: Load-displacement comparison for all different types steel frame for shear connections. 


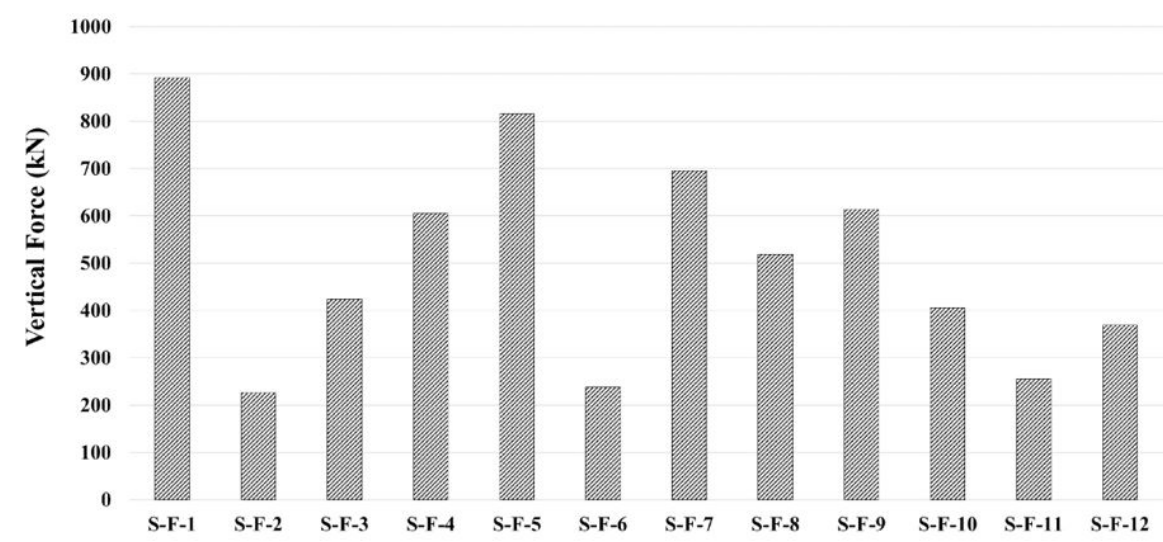

Steel frame model

(a)

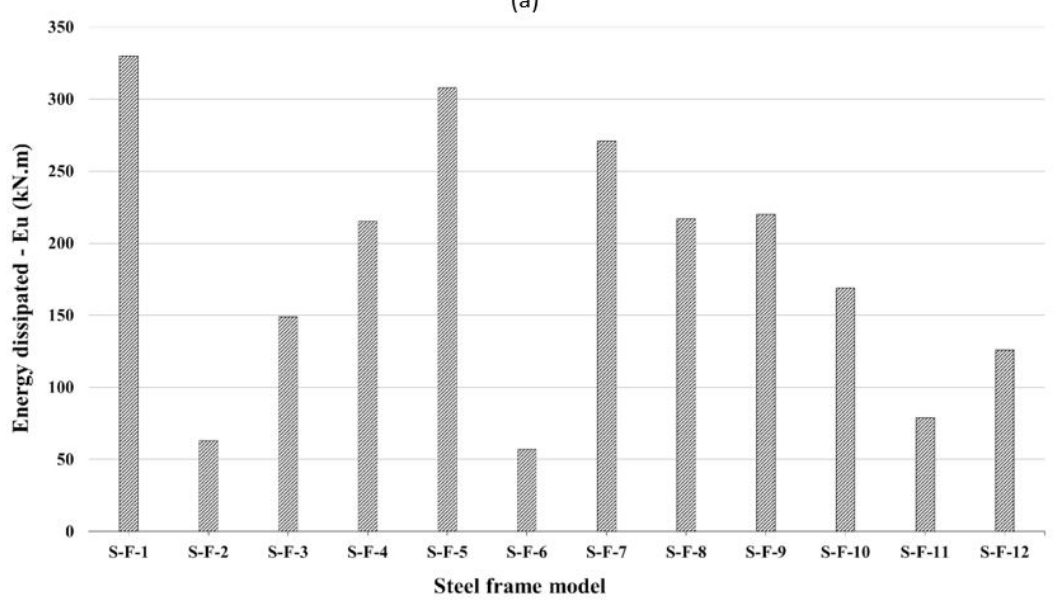

(b)

Figure 20: Comparison of all types of connections for all steel frames in terms of: (a) Peak load capacity; (b) Energy dissipated.

\section{CONCLUSIONS}

The most significant results of this study are summarized as follows:

1. I. Although the number of stories and frames had a significant impact, this role could be weakened due to the type of connection between the columns and beams, which worked to distribute the loads, thus increasing the overall resistance of the steel frame system in general.

2. II. Given the discontinuity in the steel beams at the shear beam-column connection area and the incapacity of steel beams to transfer the load of a failing steel column to neighboring members, a steel frame with a shear beamcolumn connection had an extraordinarily high likelihood of progressive collapse.

3. III. Steel frames with infill walls outperformed bare steel frames in terms of strength and initial stiffness, according to research on the subject. An additional $5 \%$ to $294 \%$ of steel frame capacity for a shear-connected steel frame was added during progressive collapse by infill.

4. IV. To determine whether infill wall placement affected progressive collapse, the researchers arranged the infill walls in vertical and horizontal rows relative to the removed steel column. Horizontally putting infill walls in the lower rows (S-F-3) outperformed horizontally placing infill walls in the upper rows (S-F-4). Placing the infill walls in vertical rows nearer to the removed column resulted in a more efficient frame (S-F-5). Buildings with shear beamcolumn connections may utilize this parameter to ensure that they do not collapse due to infill arrangement.

5. V. The presence of apertures limited the contribution of the masonry infill walls. However, complete infill walls had the potential to raise initial stiffness and maximum applied vertical load substantially. A comparison of the performance of the fully infilled frame (S-F-1) with central opening ratios of $8 \%$ (Lo=ho), $16 \%$ (Lo = 2ho), $16 \%$ ( 2 Lo $=\mathrm{ho})$, and $32 \%(2 \mathrm{Lo}=2 \mathrm{ho})$ revealed that the resisting load decreased with the increase in the opening size. The findings demonstrated the effect of changing the opening percentage on steel frame strength against progressive 
collapse. The percentage of decrease for the total frame capacity was due to the aforementioned openings as follows: $22 \%, 42 \%, 31 \%$, and $54 \%$.

6. VI. Steel infill frames S-F-1 and S-F-5 were the most resistant to progressive collapse among all prototypes, with SF-1 having the greatest progressive collapse resistance and S-F-5 having the second highest. The progressive collapse resistance of this infilled frame was approximately 3.94, 2.17, and 1.76 times greater than that of the bare frame SF-1.

\section{Acknowledgments}

The author extends his appreciation to the Princess Nourah bint Abdulrahman University Researchers Supporting Project number (PNURSP2022R271), Princess Nourah bint Abdulrahman University, Riyadh, Saudi Arabia.

Author Contributions: Conceptualization, Mohammed Alrubaidi and Alhammadi S. A; Methodology, Mohammed Alrubaidi; Investigation, Mohammed Alrubaidi and Alhammadi S. A; Writing - original draft, Mohammed Alrubaidi and Alhammadi S. A; Writing - review \& editing, Alhammadi S. A; Funding acquisition, Alhammadi S. A; Resources, Mohammed Alrubaidi and Alhammadi S. A; Supervision, Mohammed Alrubaidi.

Editor: Marcílio Alves

\section{References}

ABAQUS. Abaqus 6.20 Analysis User's Guide, Section 12.9.3 - Defining Damages, Dassault Systemes Simulia Corp., Providence, RI, 2020.

Alhammadi SA. Numerical investigation into the effectiveness of steel i-beam strengthening techniques in steel-framed buildings. Latin American Journal of Solids and Structures. 2021 Oct 22;18.

Alrubaidi M, Elsanadedy H, Abbas H, Almusallam T, Al-Salloum Y. Investigation of different steel intermediate moment frame connections under column-loss scenario. Thin-Walled Structures. 2020 Sep 1; 154:106875.

ANSI. ANSI/AISC 358-16, Prequalified Connections for Special and Intermediate Steel Moment Frames for Seismic Applications, American Institute of Steel Construction, Chicago, IL, USA, 2016a.

ANSI. ANSI/AISC 360-16, Specifications for Structural Steel Buildings, American Institute of Steel Construction, Chicago, IL, USA, 2016b.

Arasaratnam P, Sivakumaran KS, Tait MJ. True stress-true strain models for structural steel elements. ISRN Civil Engineering Vol 2011, Article ID 656401, 11 pages.

ASTM, Standard Specification for High-Strength Steel Bolts, Classes 10.9 and 10.9.3, for Structural Steel Connections (Metric). ASTM A490M-14, American Society for Testing and Materials, West Conshohocken, PA, USA, 2014.

B.D. Scott, R. Park, M.J.N. Priestley, Stress-strain behavior of concrete confined by overlapping hoops at low and high strain rates, ACI Struct. J. 79 (1) (1982)

Bao Y, Wierzbicki T. On fracture locus in the equivalent strain and stress triaxiality space. Int J Mech Sci 2004;46(1):81-98.

CEN. EN 1993-1-5 Eurocode 3: Design of steel structures - Part 1-5: General rules - Plated structural elements, 2006, Brussels.

D.C. Kent, R. Park, Flexural members with confined concrete, J. Struct. Div. 97 (7) (1971) 1969-1990.

Dinu F, Dubina D, Marginean I. Improving the structural robustness of multi-story steel-frame buildings. Structure and Infrastructure Engineering. 2015 Aug 3;11(8):1028-41.

Elsanadedy H, Alrubaidi M, Abbas H, Almusallam T, Al-Salloum Y. Progressive collapse risk of 2D and 3D steel-frame assemblies having shear connections. Journal of Constructional Steel Research. 2021 Apr 1; 179:106533.

Eren N, Brunesi E, Nascimbene R. Influence of masonry infills on the progressive collapse resistance of reinforced concrete framed buildings. Engineering Structures. 2019 Jan 1; 178:375-94. 
Fu Q, Yang B, Hu Y, Xiong G, Nie S, Zhang W, Dai G. Dynamic analyses of bolted-angle steel connections against progressive collapse based on component-based model. Journal of Constructional Steel Research. 2016 Feb 1; 117:161-74.

Khandelwal K, El-Tawil S, Sadek F. Progressive collapse analysis of seismically designed steel braced frames. Journal of Constructional Steel Research. 2009 Mar 1;65(3):699-708.

Kiakojouri F, Sheidaii MR, De Biagi V, Chiaia B. Blast-induced progressive collapse of steel moment-resisting frames: Numerical studies and a framework for updating the alternate load path method. Engineering Structures. 2021 Sep 1; 242:112541.

Kim J, An D. Evaluation of progressive collapse potential of steel moment frames considering catenary action. The structural design of tall and special buildings. 2009 Jun;18(4):455-65.

Kim J, Kim T. Assessment of progressive collapse-resisting capacity of steel moment frames. Journal of Constructional Steel Research. 2009 Jan 1;65(1):169-79.

Leyendecker EV, Ellingwood BR. Design methods for reducing the risk of progressive collapse in buildings. Washington, DC: National Bureau of Standards; 1977.

Li S, Shan S, Zhai C, Xie L. Experimental and numerical study on progressive collapse process of RC frames with full-height infill walls. Engineering Failure Analysis. 2016 Jan 1;59:57-68.

Liu C, Tan KH, Fung TC. Dynamic behaviour of web cleat connections subjected to sudden column removal scenario. J Constr Steel Res 2013;86:92-106.

McGuire W. Prevention of progressive collapse. Proc. Regional Conf. on Tall Buildings, Bangkok, Thailand; 1974.

Meng B, Zhong W, Hao J. Anti-collapse performances of steel beam-to-column assemblies with different span ratios. J Const Steel Res 2018;140:125-138.

Purnomo J, Chandra J. Evaluation of a Macro Lump Plasticity Model for Reinforced Concrete Beam-Column Connection under Cyclic Loading (Doctoral dissertation, Petra Christian University). 2020.

Qian J, Hu X. Dynamic effect analysis of progressive collapse of multi-story steel frames [J]. Journal of Earthquake Engineering and Engineering Vibration. 2008;2.

Rossi A, Nicoletti RS, Souza AS, Martins CH. Numerical assessment of lateral distortional buckling in steel-concrete composite beams. Journal of Constructional Steel Research. 2020 Sep 1;172:106192.

Sasani M, Sagiroglu S. Progressive collapse resistance of hotel San Diego. Journal of structural engineering. 2008 Mar;134(3):478-88.

Sasani M. Response of a reinforced concrete infilled-frame structure to removal of two adjacent columns. Engineering Structures. 2008 Sep 1;30(9):2478-91.

Shan S, Li S, Wang S. Effect of infill walls on mechanisms of steel frames against progressive collapse. Journal of Constructional Steel Research. 2019 Nov 1;162:105720.

Shan S, Li S, Xu S, Xie L. Experimental study on the progressive collapse performance of RC frames with infill walls. Engineering Structures. 2016 Mar 15;111:80-92.

Song $\mathrm{BI}$, Giriunas KA, Sezen H. Progressive collapse testing and analysis of a steel frame building. Journal of constructional steel research. 2014 Mar 1;94:76-83.

Song BI, Sezen H. Experimental and analytical progressive collapse assessment of a steel frame building. Engineering structures. 2013 Nov 1;56:664-72.

Tan Z, Zhong WH, Tian LM, Zheng YH, Meng B, Duan SC. Numerical study on collapse resistant performance of multi-story composite frames under a column removal scenario. Journal of Building Engineering. 2021 Dec 1;44:102957.

Tavakoli HR, Alashti AR. Evaluation of progressive collapse potential of multi-story moment resisting steel frame buildings under lateral loading. Scientia Iranica. 2013 Feb 1;20(1):77-86.

Wang F, Yang J, Nyunn S, Azim I. Effect of concrete infill walls on the progressive collapse performance of precast concrete framed substructures. Journal of Building Engineering. 2020 Nov 1;32:101461.

Wang J, Wang W. Theoretical evaluation method for the progressive collapse resistance of steel frame buildings. Journal of Constructional Steel Research. 2021 Apr 1;179:106576. 
Woodson S, Baylot J. Quarter-scale building/column experiments. In: Structures Congress 2000 - Advanced Technology in Structural Engineering; 2000.

Xavier FB, Macorini L, Izzuddin BA, Chisari C, Gattesco N, Noe S, Amadio C. Pushdown tests on masonry infilled frames for assessment of building robustness. Journal of Structural Engineering. 2017 Sep 1;143(9):04017088.

Yu J, Gan YP, Wu J, Wu H. Effect of concrete masonry infill walls on progressive collapse performance of reinforced concrete infilled frames. Engineering structures. 2019 Jul 15;191:179-93. 